Working Paper/Document de travail

2007-2

\title{
Housing Market Cycles and Duration Dependence in the United States and Canada
}

by Rose Cunningham and Ilan Kolet 
Bank of Canada Working Paper 2007-2

February 2007

\title{
Housing Market Cycles and Duration Dependence in the United States and Canada
}

\author{
by \\ Rose Cunningham and Ilan Kolet \\ International Department \\ Bank of Canada \\ Ottawa, Ontario, Canada K1A 0G9 \\ rcunningham@bankofcanada.ca \\ ikolet@bankofcanada.ca
}

Bank of Canada working papers are theoretical or empirical works-in-progress on subjects in economics and finance. The views expressed in this paper are those of the authors.

No responsibility for them should be attributed to the Bank of Canada. 


\section{Acknowledgements}

We are grateful to Larry Schembri, Robert Lafrance, Jeanine Bailliu, Don Coletti, Phillip Maier, and Marc-André Gosselin and seminar participants for helpful comments. We also thank Ryan Felushko and Joan Teske for research assistance. 


\begin{abstract}
Housing wealth is a large component of total wealth and plays an important role in aggregate business cycles. In this paper, we explore data on real house price cycles at the aggregate level and city level for the United States and Canada. Using a panel of 137 cities, we examine the duration, size, and correlations of housing market cycles in North America. We find that North American housing cycles are long, averaging five years of expansion and four years of contraction, and there is a fairly high degree of correlation in house price cycles between U.S. and Canadian cities. We estimate a discrete time survival model with a probit specification for house price expansions and contractions. This model allows us to test for duration dependence. We find that housing market expansions have positive duration dependence since their exit probabilities increase with duration, while contractions seem to have no duration dependence. Standard determinants of house prices (interest rates, income and population growth) are included as controls.

JEL classification: E32, R21, C41

Bank classification: Business fluctuations and cycles; Econometric and statistical methods
\end{abstract}

\title{
Résumé
}

L'immobilier résidentiel forme une large part de la richesse totale et joue un rôle important dans le cycle économique global. Les auteurs étudient les données relatives aux cycles des prix réels des maisons aux États-Unis et au Canada, tant à l'échelle nationale qu'au niveau des agglomérations urbaines. Ils se fondent sur un échantillon longitudinal de 137 villes pour examiner la durée, l'ampleur et la corrélation des cycles du marché du logement en Amérique du Nord. Leur analyse révèle que ce dernier connaît de longs cycles, dont les phases d'expansion et de contraction durent cinq et quatre ans respectivement, et que les cycles des prix des maisons dans les agglomérations américaines et canadiennes affichent une corrélation relativement élevée entre eux. Les auteurs estiment un modèle de survie en temps discret doté de variables probit qui permet de tester le degré de dépendance temporelle du risque de retournement des phases de hausse et de baisse. Leur modèle montre que les probabilités de retournement des phases d'expansion augmentent avec la durée, alors que celles des phases de contraction ne semblent pas sensibles au facteur temps. Les auteurs utilisent comme variables de contrôle les déterminants habituels des prix des maisons (taux d'intérêt, revenu et croissance démographique).

Classification JEL : E32, R21, C41

Classification de la Banque : Cycles et fluctuations économiques; Méthodes économétriques et statistiques 


\section{Introduction}

Housing wealth represents a large share of North American households' total wealth and changes in house prices can induce wealth effects on consumption and GDP. Both the United States and Canada have recently experienced the longest expansion in real house prices on record. A natural question is whether such a long expansion is more or less likely to terminate than a shorter one, i.e. do housing cycles exhibit duration dependence? If there is duration dependece in housing cycles then their turning points can be to some extent predicted by the duration of the phase. Thus duration could prove to be a useful indicator for policy makers. This is particularly of interest in the current context where the house price expansion in the U.S. appears to be over and Canadian house prices may soon follow.

There is evidence that business cycles, particularly recessions, have positive duration dependence, meaning they are more likely to exit the recession phase the longer its duration. This may not be surprising since policy makers and other forces in the economy are likely at work to end recession phases. Housing price cycles differ from business cycles in that housing expansions tend to be shorter than business cycle expansions, while contractions are substantially longer in duration. Therefore housing cycles may differ with respect to duration dependence as well.

The aim of this study is to examine house price expansions and contractions in the U.S. and Canada using a panel of 137 cities. The paper contributes to our understanding of housing market cycles in North America in two ways. First, we provide comparisons of the U.S. and Canada with respect to housing cycle durations, size, and correlations. Second, we estimate a discrete time survival analysis model to test for duration dependence in house price expansion and contraction phases, controlling for the effects of income, population and interest rates.

1 Table 2a compares these cycles. One possible reason for the difference in cycle patterns may be that we are comparing real house prices with real GDP growth, and downward stickiness in prices may result in house prices taking longer to adjust during a downturn than real output itself. 
Using a survival model has the advantage of investigating the effect of duration, or the length of a current phase, and the effect this has on the probability the phase will end. Furthermore, this technique may also be a useful tool to investigate the extent to which monetary policy affects the duration of housing price cycles and the timing of turning points. For this reason we have added control variables for monetary policy. Finally, our duration findings may also provide useful empirical benchmarks on the persistence of housing cycles for DSGE models that include a detailed housing sector.

This study builds on the housing cycles work of several authors detailed in the next section, but to the best of our knowledge, this is the only study that tests specifically for duration dependence in housing market cycles. One reason for the lack of duration dependence tests on house price data may be that the aggregate time series available for house prices are short relative to the length of housing market cycles. This limitation could make duration dependence estimates relatively imprecise. We address this potential problem by exploiting the cross-sectional variation available in a panel setting to improve the reliability of the estimates. ${ }^{2}$

We find that North American housing cycles average five years of expansion and four years of contraction. This compares to average business cycles with seven to ten years of expansion and just one year of contraction. There is also a fairly high degree of correlation between U.S. and Canadian cities' house price growth rates and house price cycles. We find that housing market expansions have positive duration dependence since their exit probabilities increase with duration. Contractions seem to have no duration dependence, but the results are sensitive to the particular specification. The control variables explain virtually all of the transition dynamics of contractions but there us a role for duration to help us predict expansions. This suggests that policy makers may have more traction in housing market contractions than in expansions. However, policy makers could potentially look to the

\footnotetext{
2 Panel data create more variability, through combining variation across micro units with variation over time. With this more informative data, more efficient estimation is possible.
} 
duration of an expansion cycle to help gauge when it is likely to end. This could help in the current cycle in Canada and to lesser extent in the U.S.

These findings indicate that the fundamental factors of house price cycle determination, real interest rates and real incomes largely explain the duration of housing market contractions, but leave some part of house price expansions unexplained. This may be the result of speculation or some other influence that affects housing market expansions more than contractions. Therefore it seems that policymakers are able to affect the duration of housing cycles, particularly contraction phases, through their influence on real interest rates and real incomes.

The rest of the paper is organized as follows. Section 2 discusses the related empirical literature on house price determinants and also on duration dependence. Section 3 describes the dataset. Section 4 contains the descriptive analysis and section 5 explains the estimation method. The estimation results are presented in section 6, and section 7 concludes.

\section{Related Literature}

Much of the macroeconomic literature on the housing market examines actual house prices relative to those predicted by fundamentals. Fundamental determinants of real house prices are based on a standard model of housing demand and supply. A common version of the model features housing demand as a function of prices $(P)$, household income $(Y)$, wealth $(W)$, population $(N)$, and the real user (or rental) cost of housing capital (UC). The user costs of houses are in turn a function of mortgage interest rates $\left(r_{m}\right)$, property tax rates $\left(t_{p}\right)$, income tax rates $\left(t_{y}\right)$, maintenance and repair costs $(d)$, and expected capital gains $(c g)$. The supply of housing is typically modelled as a function of prices, construction costs $(C)$ and possibly other supply shifters such as zoning or land use restrictions $(Z)$ as in Glaeser et al (2003). The model can then be expressed as a reduced form equation for the equilibrium house price $\left(P^{*}\right)$ as a function of fundamental variables: 
Demand: $Q^{D}=f\left(P, Y, W, N,\left[\left(1-\mathrm{t}_{\mathrm{y}}\right)\left(r_{m}+t_{p}\right)+d-c g\right]\right)$

Supply: $\quad Q^{S}=f(P, C, Z)$

$P^{*}=F\left(Y, W, N,\left[\left(1-\mathrm{t}_{\mathrm{y}}\right)\left(r_{m}+t_{p}\right)+d-c g\right] ; C, Z\right)$

We add control variables to our estimation model to reflect the potential influence of these types of fundamental factors on the duration house price cycles.

Recently, Girouard et al (2006) reviewed a large number of recent studies on house price developments relative to fundamentals in OECD countries. Most of these studies did not find large deviations in U.S. or Canadian house prices from their fundamental determinants. ${ }^{3}$ As these models focus on long-run relationships between house prices and fundamental variables, several studies employ error correction models. Gallin (2003) raises concerns about the validity of these models, however, by showing that house price fundamentals and house prices are not usually cointegrated, most notably income is not cointegrated with house prices, even if large panel datasets are employed. Therefore error correction models that depend on such a relationship may be misspecified. Gallin's (2004) analysis of price-to-rent ratios suggests there may be some overvaluation in current house prices in the U.S.

Himmelberg et al (2005) examine U.S. city-level data through 2004 using a detailed user-cost formula similar to the one above and conclude that house prices are not out of line with fundamentals in most cities, but they did find some cities such as Boston, San Francisco and New York were "expensive." A cross-country study by Ahearn et al (2005) show strong comovement between house prices and most other important real macroeconomic variables, but do not examine whether or not houses may be out of line with fundamental values. Van den Noord (2006) considers whether house prices are likely to peak within the next year in OECD countries, and finds that the U.S. has a high probability of being near a peak,

\footnotetext{
${ }^{3}$ There is a large related literature estimating the effect of house price changes on consumption. See for example recent papers by Case, Quigley and Shiller (2005) and Campbell and Cocco (2005). We do not examine the link between housing wealth and consumption here.
} 
especially if interest rates rise further. He does not find that Canadian house prices were likely to peak in 2005.

Martin (2005) focuses on the effect of demographic changes, building on earlier work by Mankiw and Weil (1988). Martin builds a small general equilibrium model, to examine the effect of changes in the size of the working age population on house prices and interest rates. Martin's model is able to capture the shape of the movements in U.S. house prices and interest rates over the period 1963 to 2005 quite well. Most interestingly, his model predicts that U.S. house prices will peak between 2005 and 2010, and then decline by $30 \%$ over the next 50 years.

Del Negro and Otrok (2005) analyze the extent to which house price booms are local or national phenomena. Their research suggests that while the previous housing boom in the late 1980s was driven mainly by state and regional factors, the recent boom is more of a national boom. Using a dynamic factor model, they find that the common, national component has increased in importance relative to state and regional factors during the most recent boom in all states except Florida. The authors perform the same analysis on state-level income data, but they find that the national component has not become more significant over the past 20 years. Nevertheless, the national component remains very small for some states in the Midwest and Southwest. Coastal states and small states appear to have the most exposure the national factor driving interest rates. The authors test for the effects of monetary policy as a candidate "national factor" but do not find a large effect.

Ceron and Suarez (2006) work is perhaps the most similar to ours in that they use a panel dataset and a nonlinear model to examine regime switching between housing market phases. Their method differs from ours, however, because they use a Markov switching model rather than a survival analysis framework, and they do not test for duration dependence. Ceron and Suarez (2006) find that macroeconomic fundamentals (GDP growth, interest rates and unemployment) largely explain movements of house prices at the national level and 
allowing for a Markov switching structure in prices does not add much explanatory power to predicting price movements. However, allowing Markov switching between low and high states of house price volatility however, does help predict prices, particularly price busts in that higher volatility states are associated with lower expected price growth rates.

\section{Duration Dependence Literature}

More closely related to our analysis is the literature on duration dependence in economic cycles. In microeconomic studies, survival models (also called hazard models, or duration models) are fairly common in investigating the length of time that a firm or individual remains in their current state (e.g. unemployment, bankruptcy, tenure in a job). These studies often include tests for duration dependence, i.e. whether duration in the current state influences the likelihood of continuation or exit from that state. In survival analysis terms, these authors test whether the duration of the phase affects its hazard rate, i.e. its termination probability conditional on having survived to the current period.

In empirical macroeconomics, there is also a branch of the literature that applies survival analysis techniques to examine the persistence of economic cycles, usually business cycles or stock market cycles. The main feature of these studies is that they test for duration dependence in economic cycles. That is, they test whether the age of the current phase of the cycle affects the probability that the phase will end in the next period. If duration in the phase increases the likelihood of termination, there is said to be positive duration dependence; and conversely, if duration reduces the termination probability there is negative duration dependence.

Studies that examine duration dependence in business cycle data typically use very long time series, often 50 to 100 years or more, in an attempt to have enough cycles to study. Table 1 summarizes the key findings of several studies that test for duration dependence. Three main methodologies have been used in these studies. The earliest study by Diebold and Rudebusch (1990) relied solely on nonparametric tests, as does Mills (2001). Lam (2004) and 
Durland and McCurdy (1994) test for duration dependence in the context of a Markov switching model. The most common approach, however, has been to use survival analysis models with parametric tests for duration dependence. This is the method that we use in our duration dependence analysis, described in section 7.

In general, most studies that test for duration dependence find that business cycle contractions exhibit positive duration dependence while evidence of duration dependence in expansions is mixed. Several of the authors also divide their samples into pre- and post-war periods, at times finding differing results for the two different eras. To our knowledge, Mills (2001) is one of the few duration dependence studies that include Canada. Mills examines output per capita in 22 countries and finds that for peak-to-peak and trough-to-trough horizons, both Canada and the U.S. do not exhibit duration dependence. Mills' results differ when the sample is divided into expansions and contractions. He finds that there is more evidence of negative duration dependence in contractions than expansions across countries. Canadian expansions and contractions and U.S. contractions are found to exhibit negative duration dependence.

Another set of duration studies examine duration dependence in stock market cycles. These papers normally divide the analysis into both bull and bear markets. While Lunde and Timmermann (2004) find negative duration dependence in bull markets and positive duration dependence in bear markets, Pagan and Sossounov (2001) find no conclusive evidence of duration dependence in stock market cycles.

\section{Housing Data Description}

We use annual data on real house prices at the national level and city level for the U.S. and Canada. The sample period for the U.S. house price data is 1975 to 2005, although the panel of cities is unbalanced as some cities enter the dataset as late as 1980. For Canada, the data cover 1980 to 2005, and the panel of cities is balanced. In total, our sample includes 137 cities: 
the 125 largest cities (metropolitan statistical areas) by population in the U.S., and 12 Canadian cities for which we have house price data from the real estate multiple listing service. $^{4}$

Several measures of house prices exist for the U.S. market, but, the most complete dataset is the repeat sales house price index from the Office of Federal Housing Oversight (OFHEO). We use the OFHEO nominal house price indices (HPI) for each metropolitan statistical area, and then construct real HPIs by deflating them with national-level CPI. The HPI data are considered the most useful for sub-national level analysis, but do have several limitations, mainly the upper limit on conforming loan amounts, which OFHEO estimates may omit as many as $10 \%$ of mortgages from the dataset. We also include real metro-level income and population, produced by the U.S. Bureau of Economic Analysis.

For Canada, we use annual data for the period 1980 to 2005. The nominal house price data are collected from Canadian Multiple Listing Service (MLS). Provincial level aggregates are not available, so we use the data for Canada and 12 major cities: St. John's, Halifax, Montreal, Ottawa, Toronto, Hamilton, London, Winnipeg, Regina, Calgary, Edmonton and Vancouver. Real house prices are constructed for each metro by deflating nominal average selling prices by national-level CPI. Several other variables are used as control variables in our regression analysis. These are discussed in the estimation section and in Appendix A.

\section{Descriptive Analysis}

In this section we describe some basic features of housing market cycles at the national level and in our sample of North American cities. Since we use annual data, the percentage change in real house price series is quite smooth compared to higher frequency data, and we can readily identify turning points without filtering the data. Therefore we can define an

\footnotetext{
4 The data are for metropolitan statistical areas (metros), but we refer to metros and cities interchangeably. The U.S.
} population rankings are based on metropolitan statistical areas population data for 2004 from the Census Bureau. 
expansion phase simply as a period of consecutive increases in real house prices, and a contraction phase as a series of consecutive decreases in real house prices. The housing cycle analysis presented here is for phases with a duration of two years or more.

\section{National Level Housing Cycles and Business Cycles}

Although the main purpose of this study is city-level analysis of housing price cycles, in this subsection we briefly discuss national level cycles in house prices and business cycles in the U.S. and Canada. The growth rates of real house prices at the national level are plotted in Figure 1, and Table 2a compares data on house price cycles and business cycles for the two countries.

The most recent housing cycle expansion, which began in the mid-1990s in the U.S. and a few years later in Canada, has been longer than any other in the sample period. Overall, the U.S. has had fewer national-level housing cycles than Canada, with just two contractions since 1975 compared to four in Canada since 1980. One clear pattern in the national data is that housing market cycles in Canada have tended to be shorter and have larger price movements than those in the U.S., particularly the contractions. The average house price contraction at the national level in Canada lasts just two years compared to an average of 4.5 years in the U.S., however, the accompanying price declines are as large or larger than in the U.S. in half the time. Thus the annualized growth rates over an average housing cycle in Canada have been nearly double those in the U.S. cycles. National house price cycles in the U.S. have also had considerably less real price volatility than in Canada, with a standard deviation in real price growth of $3.5 \%$, compared to $6.5 \%$ in Canada. This data is consistent with Ceron and Suarez (2006) who find that Canada has relatively more variable real house prices than most other industrialized countries in their sample of 14 countries.

Comparing the national level growth rates of real house prices over the period 1981 to 2005, we find that the two nations' house price cycles appear to be largely in phase in that correlations are fairly strong, with a contemporaneous correlation of more than 0.62 or more 
depending on the number of years included in the sample. However, U.S. house price growth seems to lead that of Canada since the growth rate of real house prices in Canada in a given year is quite strongly correlated with lagged growth rates of house prices in the U.S., at 0.62 for U.S. house price growth in the previous year, and 0.53 for two years previous.

Business cycles exhibit somewhat different duration patterns than housing cycles. We define business cycle expansions and contractions as a period of two or more consecutive quarters of real growth and declines respectively. The comparison of business cycles in the U.S. and Canada are shown in Table 2a illustrating that business cycles expansion phases are much longer than contraction phases. From 1976 to 2005, the average U.S. business cycle expansion was seven years in duration while contractions lasted less than one year on average. In Canada business cycles expansions have been similar in duration and amplitude to those in the U.S. and contractions have averaged more than twice as long as those in the U.S., but are still considerably shorter than a housing price contraction. U.S. contractions also resulted in a sharper adjustment to output than in Canada, which is opposite to the pattern with housing price contractions.

Table $2 b$ presents correlations of U.S. and Canadian national-level house price growth rates and GDP growth rates for the current year, as well as one lag and one lead. One striking feature is that the correlations between real house prices and real GDP growth in the U.S. are generally positive but not that strong, at 0.25 or less. In Canada, there is a stronger link with the highest correlation of 0.45 . In both countries the highest correlation occurs in the contemporaneous year, reducing the likelihood that house prices are a significant leading indicator of GDP growth, at least at an annual frequency. Comparing across the two countries, however, we find that U.S. house price growth in the current year and the previous year is positively and fairly highly correlated (0.46 to 0.49$)$ with this year's Canadian GDP growth. 


\section{Duration and Size of Housing Market Cycles in U.S. and Canadian Cities}

Our main focus in this study is the metro-level data, since the cross-sectional breadth of the cities dataset helps overcome the relatively short time series available for national house price data. Tables $3 \mathrm{a}$ and $3 \mathrm{~b}$ summarize counts, durations and size of the expansion and contraction phases of housing cycles in 137 North American cities.

The duration of housing market expansions in our sample ranged from two to 21 years with an average expansion lasting 5.8 years (Table $3 b$ ). The aerage and median duration of expansions in both countries are similar, but expansions in Canadian cities have a maximum duration of 12 years compared to 21 years for the U.S. cities. Furthermore the most frequently observed duration is much longer for Canadian expansions, at five years, compared to just two years in U.S. cities.

Overall, the average expansion in the sample features a real increase in house prices of $32.2 \%$ (Table $3 b)$. Based on the average duration of 5.8 years, this implies an annual growth rate in real prices of $4.95 \%$ per year. Note that we do not impose a minimum amount for the increase to be considered an expansion. Therefore the range of annual real price increases for expansions is $0.07 \%$ to $147.4 \%$. However, $90 \%$ of the expansions in the sample had real price increases of $2 \%$ or more. In the median expansion, real house prices rise by $18.3 \%$. The average size of an expansion in house prices is very similar for Canadian and U.S. cities, but in Canada there was somewhat faster annual growth rates of 5.08\% per year, compared to $4.94 \%$ in U.S. cites. Also, the median expansion in a Canadian city is larger with a real increase in prices of $26.9 \%$ compared to $16.8 \%$ in U.S. cities.

Contractions lasted from two to 12 years, with an average duration of 4.3 years in the overall sample. The most important difference we find in the city-level data is that contractions are, on average, longer in U.S. cities, with an average contraction of 4.4 years, compared to 3.5 
years in Canadian cities. ${ }^{5}$ Of the contractions that do not end in their first year, $45 \%$ of Canadian city contractions end in the second year, compared to $28 \%$ in U.S. cities.

Contractions tend to be smaller in amplitude than expansions, with average real growth in prices of $-10.8 \%$. The annualized growth rate implied by this decline, based on an average contraction duration of 4.3 years is $-2.6 \%$ per year. The range for real price growth during a contraction is $-0.03 \%$ to $-39.1 \%$. Most of the contractions (over $90 \%$ ) have real house price decreases of $1 \%$ or more. The median contraction has a price change of $-8.5 \%$.

Although the amplitudes of the contraction phases are similar for the U.S. and Canadian cities, the average contraction in Canada is shorter, with more rapid price declines indicating a sharper price correction. The average duration of a U.S. and Canadian housing market contraction is 4.4 years and 3.5 years with respective annual declines in real prices of $-2.6 \%$ and $-3.1 \%$ per year. This is consistent with the smoother cycles in the U.S. national data in Figure 1.

Table 4 presents data on housing cycles for the 10 largest U.S. cities and 12 Canadian cities. The average expansion for the U.S. cities lasted 6.4 years with an annual growth rate in real prices of $5.6 \%$, yielding a cumulative increase in real house prices in these cities of $41.7 \%$ on average. New York and Los Angeles had the largest average price increases whereby real prices increased by a total of $61.3 \%$ and $70.8 \%$ respectively during an average boom period. The greatest price increases in Canada was observed in Toronto followed by Hamilton and Montreal with average expansions of $71.3 \%, 58.7 \%$, and $48 \%$ during average boom periods.

The average contraction in the large U.S. cities' housing markets lasted 5.3 years with a total drop in real prices of $14 \%$, or $2.8 \%$ per year. This annual rate of decline is more severe than the overall sample of U.S. cities, but still less than the annual decrease observed in Canadian cities. The most severe decline occurred in Chicago, followed by Riverside and Los Angeles.

${ }^{5}$ However, given the standard deviations of the duration data there may not be a statistically significant difference. 
Of the largest U.S. cities, the longest contractions, nine years, occurred in Houston and New York. In Canada, Edmonton and Calgary have experienced the most severe contractions, while the longest housing market recession in Canada occurred in London.

\section{Synchronization of Housing Cycles in U.S. and Canadian Cities}

At the city level, we present the contemporaneous correlation of real house price growth rates between the five largest U.S. cites and five largest Canadian cities (as well as the national level data) in Table 5a.

Chicago, New York and Los Angeles have correlations greater than 0.50 with aggregate Canadian house price movements, reaching as high as 0.83 for Chicago. In Canada, the correlations are slightly weaker. The contemporaneous correlation between Montreal or Toronto and the U.S. aggregate level growth rates exceeds 0.50, while Calgary and Ottawa remain slightly below 0.50 .

Between cities, there is a high degree of correlation between Montreal and the top three American cities (0.70). There is also a fairly high correlation among several Western cities including Los Angeles, Vancouver, and Calgary. Houston exhibits the most unusual behaviour of the ten cities. Its house price growth is negative correlation with most of the selected cities. It is most closely correlated with Calgary, with a contemporaneous correlation of 0.38 , possibly due to a shared dependence on the oil industry. These correlations may suggest evidence of a common cycle between the Canadian and U.S. housing markets, or large regional cycles for eastern and western North America. Holly et al (2006) find evidence of important regional links in real house prices in their recent study of spatial dependence in real house prices in U.S. states.

We also informally examine the synchronization between house price cycles in Canada and the U.S. by simply plotting the share of sample cities in an expansion or contraction phase during the same year (See Figures 2 and 3). These shares are fairly similar in most years, but 
the small size of the Canadian sample makes it somewhat more erratic. Most remarkable is the fact that since 2002 over $90 \%$ of the sample cities in both countries have been in a housing market expansion. In 2005 only one of our sample of 137 North American cities was not in an expansion.

Table $5 \mathrm{~b}$ presents counts of the number of cities in the same housing cycle phase as the overall national level housing cycle in each country. Several characteristics stand out as being common to both regions including the breadth and timing of house price expansions and contractions, and the comovement among Canadian cities and U.S. aggregate house price cycles. We find that, on average, $70 \%$ of U.S. cities are in contractions concurrently with the national U.S. house price contraction phase. This concordance increases to $76 \%$ for U.S. expansions. It is also interesting to note that the current expansion cycle seems to differ from previous expansions. In previous expansions the number of metro areas that followed the national phase increased and then decreased symmetrically throughout the phase. In the current expansion, the number of metro areas contributing to the national level expansion has increased steadily since 1996 from $52.8 \%$ of metro areas to $99.3 \%$ of all major metro areas.

The cycles of Canadian cities closely follow the U.S. national house price cycle. Nearly $77 \%$ of Canadian cities are in an expansion when U.S. national data show an expansion. This number decreases to $72 \%$ for contractions. Not surprisingly, these results are weaker when we examine the link between major U.S. metro areas and the national Canadian house price cycle (see last column of table 6). Slightly more than half of the major U.S. metro areas are in a contraction phase when the national Canadian house price cycle is declining, while $68 \%$ of major U.S. cities are in an expansion phase at the same time as the national Canadian house price cycle. 


\section{Survival Model Estimation Strategy and Testing for Duration Dependence}

To examine more formally the durations of housing cycle phases and test for duration dependence, we estimate a regression model. Since we are interested in shifts between two discrete states (expansion or contraction), a nonlinear approach seems more appropriate than a linear regression model or an ARIMA-based approach. Survival analysis, also known as duration analysis, provides a natural framework for analyzing questions of duration. Survival analysis is commonly used in microeconomics, e.g. unemployment duration studies; however, it has also been used in several studies of economic cycles, as discussed above. Duration dependence may also be analyzed using Markov switching models based on Hamilton (1989). These models are widely-used for nonlinear analysis of macroeconomic time series. Since our dataset is organized as a panel with a large cross-sectional dimension, we employ a survival model framework for our analysis.

In survival analysis, two related probability functions are estimated, the hazard function and the survivor function. The hazard function $\left(h_{i t}\right)$, is a conditional density function describing the probability of city $i$ leaving the current state at time $t$, conditional on the current state having survived until $t-1$. The survivor function is simply one minus the hazard function, and it describes the conditional probability of the current state continuing for city $i$. In order to undertake the regression-based tests for duration dependence suggested by Ohn et al (2004), we conduct our analysis in terms of the survivor function (1- $\left.h_{i t}\right)$.

Survival analysis models may be either continuous time or discrete time models. Although many early studies employ continuous time models, discrete time models are becoming more common. This is mainly because economic data (including housing data) are usually collected at relatively low frequency, discrete intervals. Discrete time survival models are also advantageous as they can easily manage multiple spells in the data, and can have more flexible functional forms. Jenkins (1995) shows how discrete time survival models can be estimated using standard binary dependent variable estimation techniques such as logit, 
logistic, or probit specifications. This technique is described in detail in Appendix B. Below we briefly explain our probit specification.

We estimate discrete time survival models for housing cycle expansion and contraction phases. The dependent variable is a binary variable, $y_{i t}$ which represents the phase that city $i$ is in at time $t$. For example, when estimating the model for expansions, $y_{i t}=1$ if city $i$ is in an expansion phase, and $y_{i t}=0$ if that city exits the expansion phase in period $t$. This dependent variable phase is estimated using a standard probit model in which the right hand side contains a variable that measures the duration in the current phase, along with other covariates that control for fundamental factors affecting housing cycle durations. ${ }^{6}$ Specifically, we estimate the following survival model:

$$
\operatorname{Pr}(\text { Current State Continuing })=\operatorname{Pr}\left(1-h_{i t}\right)=\operatorname{Pr}\left(y_{i t}=1\right)=\Phi(X \beta)
$$

where $F$ is the cumulative normal distribution and the $X$ vector includes duration and the other covariates. In the simplest specifications, the survivor function is only a function of duration in the current state (measured in years). ${ }^{7}$

Duration dependence implies that the coefficient on the duration variable is nonzero. Since we estimate survival probabilities, a statistically significant positive coefficient implies that the longer the duration already spent in the current phase, the more likely it is to continue, which is negative duration dependence. Conversely, a significant negative coefficient on the duration variable implies positive duration dependence because it implies exit from the current state is more likely as the phase ages. A statistically insignificant coefficient means

\footnotetext{
${ }_{6}^{6}$ Although many studies of duration dependence only include duration on the right hand side of the regression, if we omit these fundamental variables then the estimated coefficients on the duration variable may be biased, as noted by Layton and Smith (2005).

7 The survival model is estimated separately for contraction and expansions since in a sample with both phases together the disturbance term may be conditionally heteroskedastic. It is not clear if robust estimation would control sufficiently for this. See Ohn et al (2004) p. 533.
} 
that the phase is duration independent, i.e. its survival probability does not depend on the time already spent in that phase.

A single continuous duration variable imposes a single coefficient on durations of different length. A more flexible specification uses dummy variables for durations of different lengths, rather than a single continuous duration variable. We are also interested in the effects of other covariates on survival probabilities, therefore we include standard deter minants of house price cycles. The literature on house price determinants suggests these controls should include income and population growth and interest rate variables. Therefore the specification becomes:

$$
\operatorname{Pr}\left(y_{i t}=1\right)=\Phi(D U R 3 . . D U R 10 U P, G I N C, G P O P, D R M)
$$

where DUR3 to DUR10UP are dummy variables for durations of different lengths from three to ten years or more, and GINC, GPOP and DRM are the growth rates of real income, the growth rate of population, and the change in the real mortgage rate. Durations of two years are the reference group for the set of duration dummy variables. The interpretation of results from probit models differs from ordinary econometric parameter estimates. The marginal effects in a probit model vary as the explanatory variables change and thus are reported in several different ways. We use a common method for estimating marginal effects which uses the mean values of the explanatory variables and discrete changes in the dummy variable regressors.

\section{Summary Statistics for Main Regression Variables}

The covariates included in our study have been summarized in Table 6. Aside from the interest rate variables, all regressors are metro level data. We find that on average real house prices grow by approximately $1.5 \%$ per year over our sample period for both Canada and the US. While the standard deviation of this mean is large $(5.7 \%)$, this may be attributable to larger than normal increases towards the end of our sample period. The growth in real income averages $2.7 \%$ per year, while the annual growth in population averages $1.3 \%$ over 
the entire sample. ${ }^{8}$ These two variables are combined to form the growth in real income per capita, which increases by $1.3 \%$ per year on average throughout our sample for both the U.S. and Canada. Also included in our set of covariates are the nominal and real policy rates for both Canada and the U.S. The nominal policy rate averages $6.5 \%$, while the real policy rate averages $3 \%$. Another variable of interest, particularly when examining the housing market, is the real mortgage rate which averages $5.6 \%$ over our sample for both Canada and the U.S. combined. The final covariate used in our duration analysis is the change in the mortgage loan-to value ratios for the U.S. major metro areas. While these ratios are unavailable for Canada, we find that in the U.S. the average mortgage loan to value ratio across our U.S. sample is $76.3 \%$.

Unit root tests indicate that the growth rates of income and population, detrended mortgage loan-to-value ratios, and the first difference of the interest rate variables are all stationary, so we use these transformed variables in our regressions. The stationarity test results are summarized in Table 7.

\section{Estimation Results}

Our first set of estimation results are presented in Tables 8 and 9. These tables contain results of basic duration dependence tests with and without controls for house price determinants. The first eight rows contain the duration variables in each of the specifications. The first row contains the variable $\operatorname{DUR}(t-1)$, the duration of the phase as of the previous period. The next rows use dummy variables for phase durations, with a duration of two years as the reference group. The dummy variables allow the influence of duration to vary by year, rather than imposing the same coefficient on durations of different lengths. The simplest specifications (1 and 2) have only duration variables and provide the basic test for duration dependence. In the remaining specifications, control variables are added, to see if duration still has

8 Although it would have been interesting to include houshold formation data in our set of covariates, this data is not available by metro level and thus has not been included. 
explanatory power. The control variables are city-specific income and population growth rates, city-specific mortgage loan to value ratios, and interest rate variables.

\section{Decade Dummy Controls}

Although all the regressors, including duration, pass unit root tests for stationarity, there may be other time-varying factors, such as financial innovation in mortgage markets, that influence the survival probabilities of housing cycle phases over different eras within our sample period. Although the secondary market for mortgages and mortgage-backed securities had existed since the early 1970s, the market had been slow to develop and not until regulatory reforms of the mid-1980s. The Secondary Mortgage Market Enhancement Act of 1984 solved many of the technical problems related to mortgage-backed securities and that the Tax Reform Act of 1986 further developed these markets. ${ }^{9}$ Green and Wachter (2005) argue that this Act also made mortgages relatively attractive investments by eliminating other interest-related personal tax deductions. Financial innovation has occurred throughout the sample period, however, Gerardi et al (2006) point out that in the mid-1990s the emergence of the sub-prime market reduced credit restrictions on a class of borrowers and has grown rapidly since. Therefore, we add decade dummies to set of control variables to control for such potential changes over time in mortgage lending with the first decade occurring from 1975 to 1984, the second from 1985 to 1994, and the final decade from 1995 to the end of the sample. ${ }^{10}$

These results are our benchmark regressions which include the decade dummies and are presented in Table 10. The decade dummies improve the fit of the models and they are statistically significant. Both decade dummies are positive for expansions indicating that, relative to the 1975 to 1984 reference period, the two most recent decades have had longer

${ }^{9}$ Gerardi et al (2006), p. 8.

10 The results did not change substantially if we split the sample into different time periods. For example, just splitting the sample in 1990 or 1995, and both indicated the most recent decade has substantially different pattern of duration dependence. This is likely driven by the fact that most of the last decade has witnessed a long expansion in most cities. Similar findings to those in Table 10 were found with a time trend, rather than decade dummies. 
lasting expansions. The reverse has occurred for contractions, in that they are significantly less likely to continue in the most recent decade relative to the reference period.

\section{Duration Dependence Tests}

Our benchmark regression specifications indicate that there is evidence of positive duration dependence in housing market expansions. The results for contractions are somewhat mixed, but generally show little evidence of duration dependence. Although the duration variables are significant and positive in all the initial regressions for expansions in Table 8, when we add decade dummies in Table 10 we find that duration still has significant explanatory power, but the sign changes. Despite this sensitivity, the results in Table 10 should be given more weight since the decade dummies have large and highly statistically significant coefficients.

The results in Table 10 indicate that for expansions, the duration variables all have negative and statistically significant coefficients. This means that the longer the expansion has already lasted, the less likely it is survive another year, which implies that housing market expansions have positive duration dependence (i.e. more likely to exit the expansion with age). This finding is consistent with the results of Layton and Smith (2005) and Zuelke (2003) for business cycle expansions.

The overall negative effect of duration on expansion phases seems to be driven by expansions of five years or older, since the duration dummy coefficients indicate that shorter duration phases are equally likely to survive, but beyond five or six years phases are significantly less likely to survive. Thus it seems duration dependence varies over phase lengths.

Contractions show little evidence of significant duration dependence in the results in Table 10. The duration dummy variables have mixed signs and are often not significant. Short 
durations of three or four years tend to have positive coefficients. Very long durations of nine or more years, have significantly negative survival probabilities. After controlling for other city-specific effects (Table 11), however, some models show weakly positive duration dependence. Overall, however, duration dependence in contractions does not seem to be robust to the inclusion of other variables.

\section{Controlling for House Price Fundamentals}

We add four types of variables to control for fundamental factors affecting house prices, based on the literature: real income growth, population growth, interest rates, and mortgage loan to value ratios (credit conditions). ${ }^{11}$ These variables generally have the expected signs. Higher growth in real income, or income per capita, tends to increase the probability that a house price expansion phase will continue, and decreases the continuation probability of contractions. Accelerations in interest rates (real mortgage rates, real or nominal policy rates) tend to decrease the survival probability of expansions, and increase the continuation probability for contractions. Interestingly, population growth alone (after controlling for income growth) tends to decrease the probability that a housing price expansion continues, while raising the probability that a contractions will continue. We also include lagged value of average mortgage loan to value ratios above their historical trend, which have small and insignificant effects. ${ }^{12}$

The significance of the real mortgage interest rate variable, $D R M$, is sensitive to the inclusion of the decade dummy variables, although its sign does not change. However, we find that the effects of the real policy rate variable is robust to all our specification changes, and its effect on survival probabilities is fairly large. In particular, for contractions, DRPOLICY has a large effect of roughly the same magnitude as growth in income per capita.

\footnotetext{
${ }_{11}$ Aside from interest rate variables, all regressors are metro level specific.

12 Using one or two lags of population growth rather than the contemporaneous value, we find the same signs and the coefficients remain significant.
} 
There were coefficients on the dummy variable for Canada that tended to be very sensitive to the inclusion of dummy variables and other robustness tests. In several models of contractions, the dummy for Canadian cities becomes negative and significant, suggesting that Canadian contractions are shorter than those in U.S. cities, which is consistent with the findings in the unconditional descriptive statistics described above.

\section{Robustness of Estimation Results}

The high degree of concordance in housing cycle phases among our sample cities implies that it is unlikely that the observed phases in our sample are independent of each another. Therefore, we also control for potentially nonspherical errors arising from this spatial dependence in our regression estimates. We do so by allowing the errors to be clustered by region or state/province, which means that the regression errors for city-observations within the cluster may not be independently distributed. It is also possible that there is more heterogeneity among cities than we have assumed so far, perhaps due to different municipal tax rates, or zoning restrictions. Therefore we also add city-specific dummy variables, or fixed effects, to our benchmark regression specification (Table 11 models 5 and 10). Finally we test the benchmark specification without imposing a minimum duration on the phase lengths. The results of these additional robustness tests are presented in Table 11.

The duration dependence results for expansions are remarkably robust to both the clustering and the addition of the city fixed effects, but the contraction results are more sensitive to the clustering effects. There is some weak evidence of positive duration dependence in contractions, but it is only significant at the $10 \%$ level in two models. The effects of the other covariates are very similar to the benchmark regressions in Table 10.

\section{Implications}

Our findings show that control variables, including real and nominal interest rates, largely explain contractions in house price cycles. Expansion phases, however are not completely 
explained using the standard house price determinants, but are found to exhibit duration dependence. These results are interesting for policy makers for several reasons.

First, the findings suggest that monetary policy has a significant amount of traction in explaining the transition out of both contractions and expansions Second, the fact that duration is significant for expansion phases could prove to be a useful indicator in predicting the length of housing market expansions. Finally, it is striking that there is an asymmetric nature to our duration dependence findings in that only expansion phases exhibit significant duration dependence. This may occur because duration acts like a proxy for other, omitted, variables that explain the transition out of housing market expansions. One potential interpretation is that the duration dependence we find in expansion cycles is a proxy for speculative activity. Speculation may only appear in expansion phases because, unlike other asset markets, short selling of houses is really not possible. ${ }^{13}$ This may be why we find duration to be significant only in the expansion survival estimates.

\section{Summary and Conclusions}

Housing cycles in the U.S. and Canada are quite similar overall, but Canadian housing market cycles are more volatile than those in the U.S. Most notably, Canadian housing market contractions are somewhat shorter and sharper than those in U.S. cities. An average expansion lasts from five to six years in both countries and is characterized by an average increase in real prices of about $32 \%$, although the median expansion is larger in Canadian cities (26\% versus $18 \%$ growth) in our sample. In both countries, real house prices decline by $10 \%$ to $11 \%$ during an average contraction. This price decline however, occurs more rapidly in Canada since the average contraction lasts only 3.5 years in Canadian cities compared to 4.4 years in the U.S. cities.

13 The literature on housing price bubbles and monetary policy examines this in more detail. See for example Herring and Wachter(2002). 
Real house price growth rates in the two countries are quite strongly correlated at the national level and among the largest cities in both countries. Canadian cities are in the same housing cycle phase as that of the U.S. $70 \%$ of the time. Future work could examine the possibility that there is a common housing cycle in Canada and the U.S. or in broad North American regions. This would be of interest since our findings suggest a clear link between the housing markets of the two countries, yet housing is a non-tradable product.

Real policy rates and the growth of income per capita appear to have strong effects on the transition probabilities of housing market expansions and contractions. After controlling for these fundamental variables and decade-specific time effects, we still find considerable positive duration dependence in expansions, but little evidence of duration dependence in contractions. These findings suggest that fundamental factors do a fairly good job of explaining the transition of housing markets out of contractions phases.

Therefore, to the extent that policy-makers influence real income growth and real interest rates, they are likely to have a substantial effect on the duration of housing market contractions. However, the existence of significant positive duration dependence in expansion phases probably means that there are other factors such as speculation, overbuilding and surplus inventories that drive the transition of housing markets out of expansion and into contraction. Furthermore, the duration dependence result in expansion cycles could also prove to be a useful tool for policy makers simply because it may help predict housing market turning points. So, while rising incomes and lower interest rates almost certainly played a role in the continuation of the long housing expansion that most cities in the U.S. and Canada recently experienced, these factors alone cannot fully explain its extraordinary duration. 


\section{References:}

Ahearn, A., J. Ammer, B. Doyle, L. Kole, and R. Martin. 2005. "House Prices and Monetary Policy: A Cross-Country Study," International Finance Discussion Paper Series No. 841, Federal Reserve Board.

Allan, J., R. Amano, D. Byrne, and A. Gregory. 2006. “Canadian City Housing Prices and Urban Market Segmentation" unpublished mimeo.

Cameron, G., J. Muellbauer, and A. Murphy. 2006. "Was there a British House Price Bubble? Evidence from a Regional Panel," Centre for Economic Policy Research Discussion Paper No. 5619. April.

Campbell, J.Y and J. Cocco. 2005. "How Do House Prices Affect Consumption? Evidence from Micro Data." NBER Working Paper 11534.

Case, K.E., J.M. Quigley, and R. J. Shiller. 2005. "Comparing Wealth Effects: The Stock Market versus the Housing Market." Advances in Macroeconomics, 5(1).

Ceron, J. and J. Suarez. 2006. "Hot and Cold Housing Markets: International Evidence," Centre for Monetary and Financial Studies (CEMFI) Working Paper 0603. Madrid: Banco d' Espana.

Cho, M. 1996. "House Price Dynamics: A Survey of Theoretical and Empirical Issues," Journal of Housing Research , 7(2), 145-172.

Di Venuto, N. and A. Layton. 2005. "Do the Phases of the Business Cycle Die of Old Age?" Australian Economic Papers, 44, 291-305.

Diebold, F.X., G.D. Rudebusch, and D.E. Sichel. 1993. "Further Evidence on Business Cycle Duration Dependence," in J.H. Stock and M.W. Watson (eds) Business Cycles, Indicators, and Forecasting, 87-116.

Diebold, F.X. and G.D. Rudebusch. 1990. "A Nonparametric Investigation of Duration Dependence in the American Business Cycle," Journal of Political Economy, 88(3). 596-616.

Durland, J.M. and T.H. McCurdy. 1994. "Duration-Dependent Transitions in a Markov Model of U.S. GNP Growth," Journal of Business and Economic Statistics, 12(3), 279-288.

Gallin, J. 2003. "The Long-Run Relationship between Home Prices and Income: Evidence from Local Housing Markets." Finance and Economics Discussion Series, No.2003-17, Federal Reserve Board. 
Gallin, J. 2004. "The Long-Run Relationship between Home Prices and Rents," Finance and Economics Discussion Series, No.2004-50, Federal Reserve Board.

Gerardi, K., H. Rosen, and P. Willen. 2006. "Do Households Benefit from Financial Deregulation and Innovation? The Case of the Mortgage Market." Federal Reserve Bank of Boston Pub lic Policy Discussion Paper 06-6.

Girouard, N., M. Kennedy, P. van den Noord, and C. Andre. 2006. "Recent House Price Developments: The Role of Fundamentals," OECD Economics Department Working Papers No. 475. Paris: OECD Publishing.

Glaeser, E. J. Gyourko, and R. Saks. 2003. “Why is Manhattan So Expensive? Regulation and the Rise of House Prices," Harvard Institute of Economic Research Discussion Paper 2020. November, 2003.

Green, R.K. and S. M. Wachter. 2005. "The American Mortgage in Historical and International Context," Journal of Economic Perspectives, 19(4). 93-114.

Herring, R., S. Wachter. 2002. "Bubbles in Real Estate Markets," Working Paper. Zell/Lurie Real Estate Center. March, 2002.

Himmelberg, C., C. Mayer, and T. Sinai. 2005. “Assessing High House Prices: Bubbles, Fundamentals and Misperceptions," NBER Working Paper No. 11643.

Holly, S., M. Pesaran, and T. Yamagata. 2006. "A Spatio-Temporal Model of House Prices in the U.S." Working Paper. University of Cambridge. Sept., 2006.

Jenkins, S.P. 2004. Survival Analysis. Unpublished manuscript. July, 2004.

Jenkins, S.P. 1995. "Easy Estimation Methods for Discrete-Time Duration Models," Oxford Bulletin of Economics and Statistics, 57(1), 129-137.

Kishor, N.K. 2005. "Does Consumption Respond More to Housing Wealth than to Financial Wealth? If So, Why? Unpublished manuscript, University of Washington, Department of Economics. June 2005.

Lam, P.-S. 2004. "A Markov-Switching Model of GNP Growth with Duration Dependence," International Economic Review, 45(1). 175-204.

Layton, A.P. and D.R. Smith. 2005. "Business Cycle Dynamics with Duration Dependence and Leading Indicators," mimeo. 
Lunde, A. and A. Timmermann. 2004. "Duration Dependence in Stock Prices: An Analysis of Bull and Bear Markets," Journal of Business and Economic Statistics, 22(3), 253 -273.

Martin, R. 2005. "The Baby Boom: Predictability in House Prices and Interest Rates," International Finance Discussion Paper Series No. 847, Federal Reserve Board.

Mills, T.C. 2001. "Business Cycle Asymmetry and Duration Dependence: An International Perspective," Journal of Applied Statistics, 28(6). 713-724.

Ohn, J., L.W. Taylor, and A. Pagan. 2004. "Testing for Duration Dependence in Economic Cycles," Econometrics Journal. 528-549.

Sichel, D.E. 1990."Business Cycle Duration Dependence: A Parametric Approach," Review of Economics and Statistics, 73, 254-260.

Van den Noord, P. 2006. "Are House Prices Nearing a Peak? A Probit Analysis for 17 OECD Countries" OECD Economics Department Working Papers. Paris: OECD Publishing.

Zuehlke. T.W. 2003. "Business Cycle Duration Dependence Reconsidered," Journal of Business and Economic Statistics, 21(4), 564-569. 
Figure 1: Growth Rates of Real House Prices, National Level Averages (y/y)
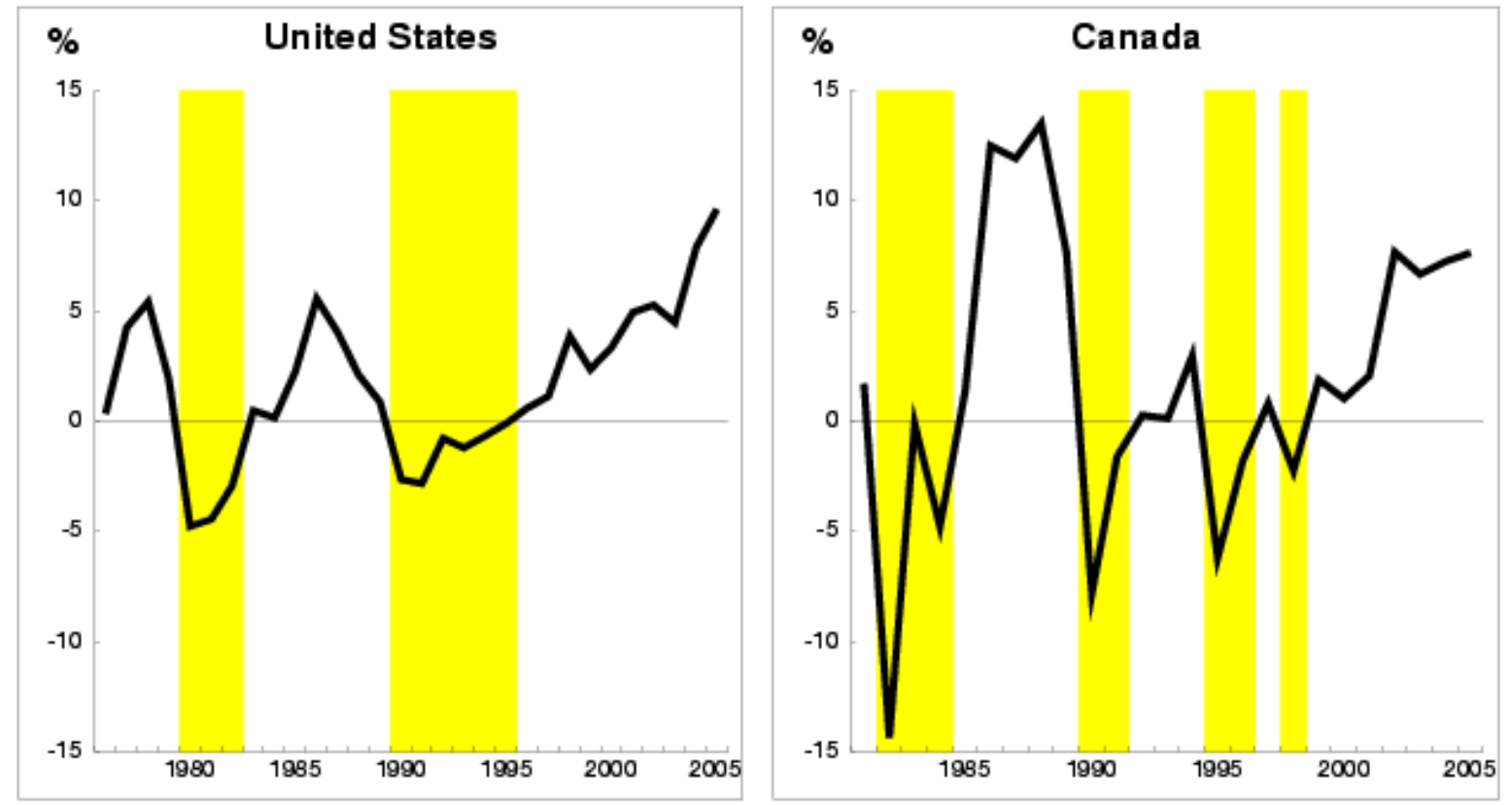

Note: Sample periods are 1976 to 2005 for the U.S. and 1981 to 2005 for Canada. 
Figure 2: Percentage of Sample Cities in Expansion Phase Each Year

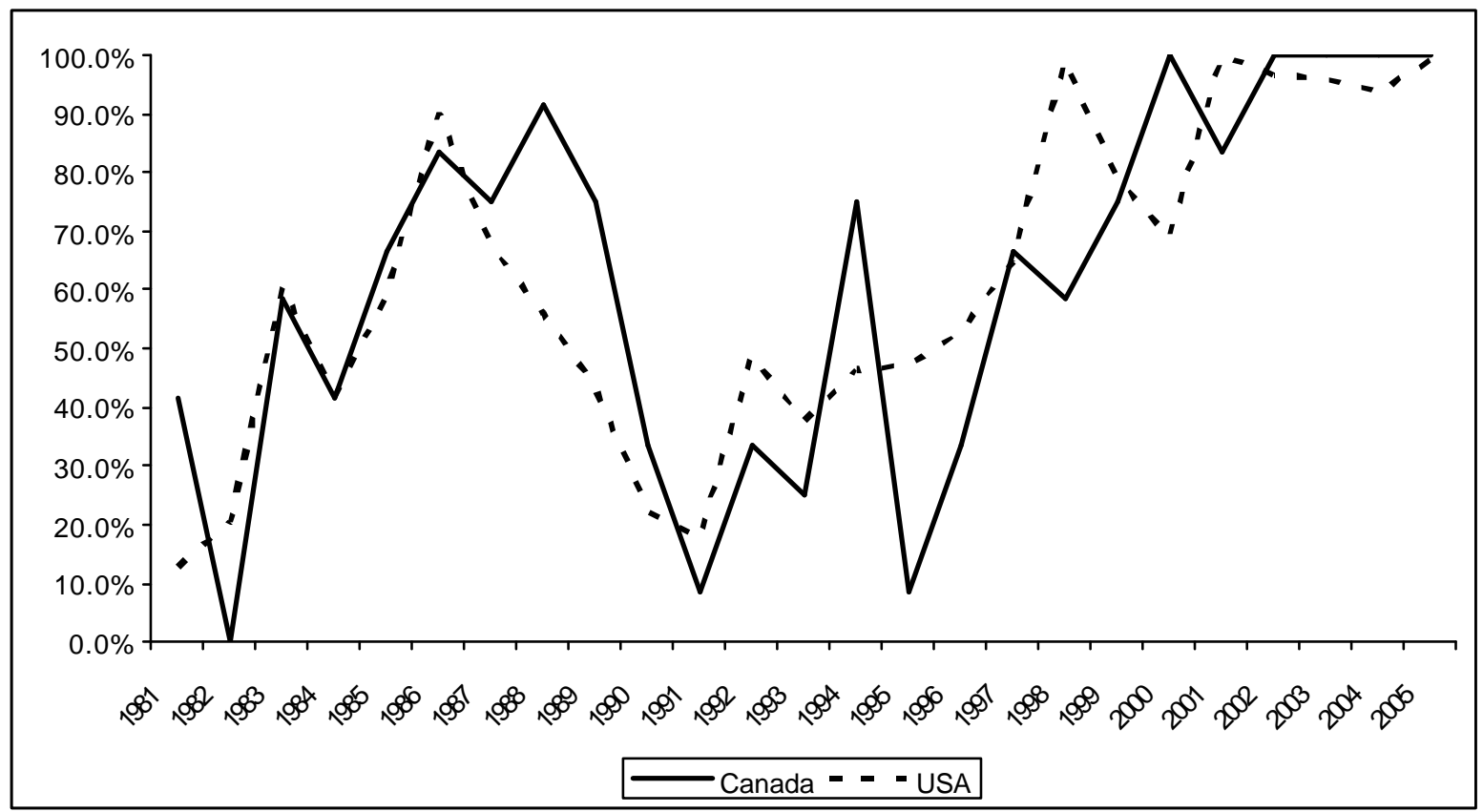


Table 1: Summary of Literature on Duration Dependence in Economic or Financial Market Cycles

\begin{tabular}{|c|c|c|c|}
\hline Layton and Smith (2005) & U.S. Business Cycles & 1949 to 2002 & $\begin{array}{l}\text { Evidence of positive duration dependence is } \\
\text { found in recessions and expansions (some of } \\
\text { the time). }\end{array}$ \\
\hline $\begin{array}{l}\text { Di Venuto and Layton } \\
\text { (2005) }\end{array}$ & $\begin{array}{l}\text { Australian Business } \\
\text { Cycle Movements }\end{array}$ & Post WWII to 2002 & $\begin{array}{l}\text { Duration dependence in Australian business } \\
\text { cycles. }\end{array}$ \\
\hline $\begin{array}{l}\text { Ohn, Taylor, and Pagan } \\
\text { (2004) }\end{array}$ & $\begin{array}{l}\text { U.S. Business and Stock } \\
\text { Market Cycles }\end{array}$ & $\begin{array}{l}1837 \text { to } 1994 \\
\text { (Stocks) } \\
1854 \text { to } 1989 \\
\text { (Business Cycles) }\end{array}$ & $\begin{array}{l}\text { Positive duration dependence in pre - and } \\
\text { post-war contractions. Positive duration } \\
\text { dependence in bull and bear markets } \\
\text { (several periods used in specification). }\end{array}$ \\
\hline Lam (2004) & U.S. Business Cycles & 1952 to 2001 & $\begin{array}{l}\text { Negative duration dependence in } \\
\text { expansions, and positive duration } \\
\text { dependence in contractions. }\end{array}$ \\
\hline Zuehlke (2003) & US Business Cycles & 1954 to 2001 & $\begin{array}{l}\text { Positive duration dependence for both } \\
\text { expansions and contractions. }\end{array}$ \\
\hline Mills (2001) & $\begin{array}{l}\text { Output per Capita, } \\
22 \text { countries }\end{array}$ & $\begin{array}{l}\text { Varying start dates } \\
\text { from } 1870 \text { to } 1911\end{array}$ & $\begin{array}{l}\text { Evidence of duration dependence in } \\
\text { contractions and in expansions for some } \\
\text { countries, including the U.S. Canada has } \\
\text { duration dependence in both. }\end{array}$ \\
\hline $\begin{array}{l}\text { Durland and McCurdy } \\
\text { (1994) }\end{array}$ & U.S. Business Cycles & 1952 to 1984 & $\begin{array}{l}\text { No duration dependence found in U.S. } \\
\text { expansions. Positive duration dependence in } \\
\text { contractions. }\end{array}$ \\
\hline Sichel (1991) & U.S. Business Cycles & 1854 to 1990 & $\begin{array}{l}\text { Positive duration dependence in pre -war } \\
\text { expansions and post-war contractions. }\end{array}$ \\
\hline $\begin{array}{l}\text { Diebold, Rudebusch, } \\
\text { and Sichel (1991) }\end{array}$ & $\begin{array}{l}\text { Business Cycles for US, } \\
\text { France, Germany, Great } \\
\text { Britain }\end{array}$ & 1854 to 1982 & $\begin{array}{l}\text { Less positive duration dependence in } \\
\text { postwar U.S. business cycle expansions, } \\
\text { more duration dependence in post-war } \\
\text { contractions. Positive duration dependence } \\
\text { found in pre-ward expansions for other four } \\
\text { countries. }\end{array}$ \\
\hline $\begin{array}{l}\text { Diebold and Rudebusch } \\
\text { (1990) }\end{array}$ & U.S. Business Cycles & 1854 to 1989 & $\begin{array}{l}\text { Mixed evidence of duration dependence } \\
\text { found. Results sensitive to sam ple period. }\end{array}$ \\
\hline $\begin{array}{l}\text { Lunde and } \\
\text { Timmermann (2004) }\end{array}$ & U.S. Stock Prices & 1885 to 1997 & $\begin{array}{l}\text { Negative duration dependence in bull } \\
\text { markets, positive duration dependence in } \\
\text { bear markets. }\end{array}$ \\
\hline $\begin{array}{l}\text { Pagan and Sossounov } \\
\text { (2001) }\end{array}$ & U.S. Stock Market Cycles & 1835 to 1997 & $\begin{array}{l}\text { No conclusive evidence of duration } \\
\text { dependence found. }\end{array}$ \\
\hline
\end{tabular}


Table 2a: D uration and Amplitude of Housing and Business Cycle Phases in the U.S. and Canada14

\begin{tabular}{|c|c|c|c|c|c|c|c|c|}
\hline & \multicolumn{2}{|c|}{ Number of Phases } & \multicolumn{2}{|c|}{ A verage Duration (Years) } & \multicolumn{2}{|c|}{ A verage A mplitude (\%) } & \multicolumn{2}{|c|}{ Avg. Annual Growth (\%) } \\
\hline & Expansions & Contractions & Expansions & Contractions & Expansions & Contractions & Expansions & Contractions \\
\hline \multicolumn{9}{|c|}{ H ousing Price $C$ ycles } \\
\hline U.S. & 3 & 2 & 7.00 & 4.50 & 27.01 & -9.82 & 3.47 & -2.30 \\
\hline CANADA & 4 & 4 & 3.60 & 2.00 & 24.85 & -9.50 & 6.36 & -4.87 \\
\hline \multicolumn{9}{|c|}{ Business Cycles } \\
\hline U.S. & 4 & 3 & 7.50 & 0.50 & 31.76 & -2.10 & 3.75 & -4.16 \\
\hline CANADA & 3 & 2 & 7.75 & 1.25 & 32.65 & -4.13 & 3.71 & -3.32 \\
\hline
\end{tabular}

Table 2b: Correlations of Real H ouse Price (H P) G rowth and Real G D P G rowth in the U.S. and Canada, 1982 to 2004

\begin{tabular}{|c|c|c|c|c|c|c|c|c|c|c|c|c|}
\hline & $\begin{array}{l}\text { U.S. HP } \\
(\mathrm{t}-1)\end{array}$ & $\begin{array}{l}\text { U.S. HP } \\
\text { (t) }\end{array}$ & $\begin{array}{l}\text { U.S. HP } \\
(\mathrm{t}+1)\end{array}$ & $\begin{array}{c}\text { CAN } \\
\mathrm{HP}(\mathrm{t}-1)\end{array}$ & $\begin{array}{l}\text { CAN } \\
\mathrm{HP}(\mathrm{t})\end{array}$ & $\begin{array}{c}\text { CAN } \\
\text { HP } \\
(t+1)\end{array}$ & $\begin{array}{l}\text { U.S. } \\
\text { GDP } \\
\text { (t-1) }\end{array}$ & $\begin{array}{l}\text { U.S. } \\
\text { GDP (t) }\end{array}$ & $\begin{array}{l}\text { U.S. } \\
\text { GDP } \\
(\mathrm{t}+1)\end{array}$ & $\begin{array}{l}\text { CAN } \\
\text { GDP } \\
\text { (t-1) }\end{array}$ & $\begin{array}{l}\text { CAN } \\
\text { GDP (t) }\end{array}$ & $\begin{array}{l}\text { CAN } \\
\text { GDP } \\
(t+1)\end{array}$ \\
\hline U.S. HP (t-1) & 1.00 & & & & & & & & & & & \\
\hline U.S. HP (t) & 0.80 & 1.00 & & & & & & & & & & \\
\hline U.S. HP $(t+1)$ & 0.59 & 0.82 & 1.00 & & & & & & & & & \\
\hline CAN HP (t-1) & 0.61 & 0.28 & 0.05 & 1.00 & & & & & & & & \\
\hline CAN HP (t) & 0.71 & 0.68 & 0.35 & 0.41 & 1.00 & & & & & & & \\
\hline CAN HP $(t+1)$ & 0.57 & 0.64 & 0.62 & 0.24 & 0.51 & 1.00 & & & & & & \\
\hline U.S. GDP (t-1) & 0.25 & 0.13 & 0.18 & 0.30 & 0.00 & 0.29 & 1.00 & & & & & \\
\hline U.S. GDP (t) & 0.23 & 0.26 & 0.14 & -0.04 & 0.32 & -0.02 & 0.21 & 1.00 & & & & \\
\hline U.S. GDP $(t+1)$ & -0.28 & -0.03 & 0.05 & -0.46 & -0.05 & 0.00 & -0.33 & 0.21 & 1.00 & & & \\
\hline CAN GDP (t-1) & 0.42 & 0.32 & 0.29 & 0.44 & 0.10 & 0.30 & 0.83 & -0.01 & -0.40 & 1.00 & & \\
\hline CAN GDP (t) & 0.49 & 0.46 & 0.34 & 0.13 & 0.45 & 0.17 & 0.40 & 0.84 & 0.04 & 0.30 & 1.00 & \\
\hline CAN GDP $(t+1)$ & 0.05 & 0.30 & 0.30 & -0.35 & 0.16 & 0.22 & -0.09 & 0.44 & 0.77 & -0.17 & 0.40 & 1.00 \\
\hline
\end{tabular}

14 The sample period is 1976 to 2005 for the U.S. and 1981 to 2005 for Canada. Business cycles are identified as a period of two or more consecutive quarters of real GDP growth (expansions) or decline (contractions), and housing cycles are simply an increase or decline in the annual growth rates of real house prices. 
Table 3a: Number of Housing Market Expansions and Contraction Phases in U.S. and Canadian Cities 15

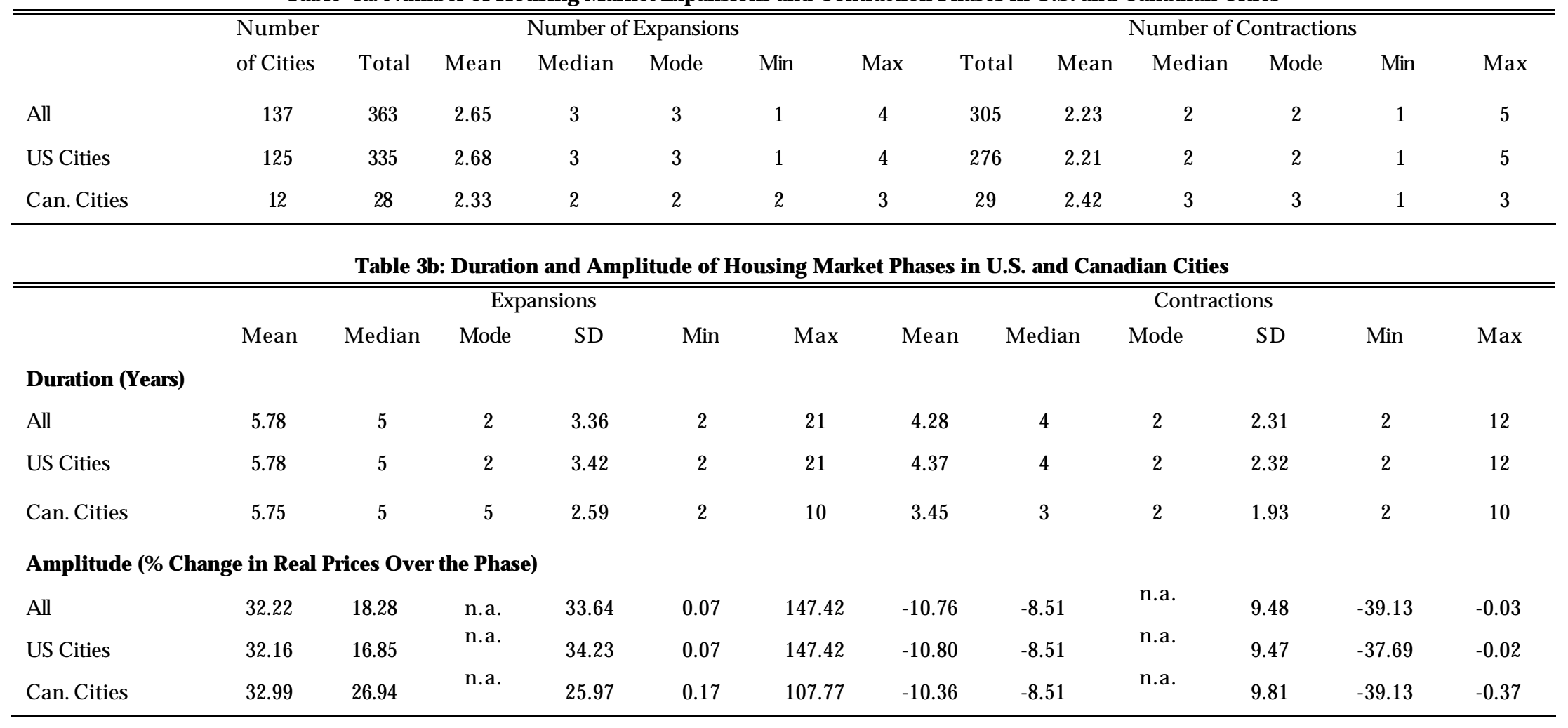

15 The sample period for the U.S. is 1976 to 2005 and 1981 to 2005 for Canada. 


\begin{tabular}{|c|c|c|c|c|c|c|c|c|c|c|c|c|c|c|c|c|}
\hline & \multicolumn{8}{|c|}{ Expansions } & \multicolumn{8}{|c|}{ Contractions } \\
\hline & \multicolumn{4}{|c|}{ Duration (years) } & \multicolumn{4}{|c|}{ Amplitude (\% chg real prices) } & \multirow[b]{2}{*}{$\mathrm{N}$} & \multicolumn{3}{|c|}{ Duration (years) } & \multicolumn{4}{|c|}{ Amplitude (\% chg real prices) } \\
\hline & $\mathrm{N}$ & Mean & Min & Max & Mean & SD & Min & Max & & Mean & Min & Max & Mean & SD & Min & Max \\
\hline Atlanta, GA & 2 & 8.5 & 6 & 11 & 23.6 & 17.5 & 11.3 & 36.0 & 2 & 5.0 & 4 & 6 & -6.3 & 4.4 & -9.4 & -3.2 \\
\hline Chicago, IL & 3 & 8.3 & 3 & 14 & 30.4 & 14.7 & 16.8 & 46.0 & 1 & 4.0 & 4 & 4 & -22.5 & 0.0 & -22.5 & -22.5 \\
\hline Dallas, TX & 3 & 5.0 & 3 & 8 & 12.7 & 7.8 & 3.7 & 18.1 & 2 & 6.0 & 3 & 9 & -14.1 & 18.0 & -26.8 & -1.4 \\
\hline Houston, TX & 2 & 6.0 & 3 & 9 & 16.3 & 12.6 & 7.4 & 25.3 & 4 & 3.5 & 2 & 6 & -11.2 & 15.4 & -34.1 & -0.9 \\
\hline Los Angeles, CA & 3 & 6.3 & 5 & 8 & 70.8 & 37.4 & 41.6 & 112.9 & 2 & 5.5 & 4 & 7 & -17.8 & 17.4 & -30.1 & -5.4 \\
\hline New York, NY & 3 & 5.3 & 2 & 8 & 61.3 & 47.0 & 7.5 & 93.9 & 2 & 6.0 & 3 & 9 & -13.1 & 15.9 & -24.3 & -1.9 \\
\hline Philadelphia, PA & 2 & 7.5 & 7 & 8 & 53.9 & 1.7 & 52.8 & 55.2 & 2 & 7.0 & 6 & 8 & -15.1 & 1.5 & -16.2 & -14.1 \\
\hline Phoenix, AZ & 3 & 5.3 & 2 & 12 & 33.5 & 47.3 & 3.5 & 88.1 & 2 & 5.0 & 3 & 7 & -13.8 & 10.1 & -20.9 & -6.7 \\
\hline Riverside, CA & 3 & 5.3 & 3 & 8 & 55.7 & 55.5 & 18.3 & 119.6 & 2 & 6.5 & 6 & 7 & -20.3 & 14.2 & -30.4 & -10.3 \\
\hline Washington, DC & 3 & 6.3 & 4 & 8 & 48.4 & 42.7 & 9.9 & 94.3 & 2 & 5.5 & 3 & 8 & -12.5 & 6.6 & -17.2 & -7.9 \\
\hline Total, 10 Largest & 27 & 6.4 & 2 & 14 & 41.7 & 35.3 & 3.5 & 119.6 & 21 & 5.3 & 2 & 9 & -14.0 & 10.7 & -34.1 & -0.9 \\
\hline Total U.S. Cities & 335 & 5.8 & 2 & 21 & 32.2 & 16.9 & 0.1 & 147.4 & 276 & 4.4 & 2 & 12 & -10.8 & 9.5 & 37.7 & -0.0 \\
\hline Calgary, AB & 2 & 7.5 & 5 & 10 & 39.5 & 22.2 & 23.8 & 55.2 & 3 & 3.7 & 2 & 4 & -12.4 & 18.9 & -34.2 & -0.4 \\
\hline Edmonton, $\mathrm{AB}$ & 2 & 7.0 & 5 & 9 & 30.0 & 23.4 & 13.4 & 46.6 & 2 & 4.5 & 2 & 7 & -20.7 & 26.0 & -39.1 & -2.3 \\
\hline Halifax, NS & 3 & 5.0 & 2 & 10 & 19.0 & 25.9 & 1.5 & 48.9 & 2 & 3.5 & 2 & 5 & -6.3 & 3.1 & -8.5 & -4.1 \\
\hline Hamilton, ON & 2 & 7.0 & 5 & 9 & 58.7 & 43.3 & 28.0 & 89.3 & 3 & 2.7 & 2 & 4 & -10.2 & 10.1 & -20.6 & -0.5 \\
\hline London, ON & 2 & 4.5 & 4 & 5 & 39.4 & 31.6 & 17.1 & 61.8 & 2 & 6.0 & 2 & 10 & -16.7 & 2.5 & -18.4 & -14.9 \\
\hline Montreal, QC & 2 & 8.0 & 7 & 9 & 48.0 & 12.3 & 39.3 & 56.6 & 1 & 7.0 & 7 & 7 & -14.9 & 0.0 & -14.9 & -14.9 \\
\hline Ottawa, ON & 3 & 4.3 & 3 & 7 & 21.6 & 20.6 & 5.1 & 44.8 & 3 & 2.7 & 2 & 4 & -3.9 & 1.4 & -5.3 & -2.6 \\
\hline Regina,SK & 3 & 4.3 & 2 & 9 & 9.39 & 14.3 & 0.2 & 25.8 & 2 & 3.0 & 3 & 3 & -9.6 & 7.3 & -14.7 & -4.4 \\
\hline St. Johns, NF & 2 & 7.5 & 7 & 8 & 22.3 & 11.5 & 14.2 & 30.4 & 3 & 2.3 & 2 & 3 & -5.8 & 6.0 & -12.7 & -2.2 \\
\hline Toronto, ON & 2 & 7.0 & 5 & 9 & 71.3 & 51.6 & 34.8 & 107.8 & 3 & 3.0 & 2 & 4 & -9.4 & 12.5 & -23.8 & -1.1 \\
\hline Vancouver, BC & 3 & 4.0 & 3 & 5 & 37.1 & 18.4 & 21.8 & 57.4 & 2 & 4.5 & 4 & 5 & -12.5 & 2.4 & -14.2 & -10.8 \\
\hline Winnipeg, MB & 2 & 5.5 & 5 & 6 & 22.1 & 4.1 & 19.2 & 24.9 & 3 & 3.3 & 2 & 5 & -10.4 & 6.3 & -14.2 & -2.4 \\
\hline Total Can. Cities & 28 & 5.8 & 2 & 10 & 33.0 & 26.0 & 0.2 & 107.8 & 29 & 3.4 & 2 & 10 & -10.4 & 9.8 & -39.1 & -0.4 \\
\hline
\end{tabular}


Table 5a: Contemporaneous Correlation of Growth Rates of House Prices in Major U.S. and Canadian Cities

\begin{tabular}{|c|c|c|c|c|c|c|c|c|c|c|c|c|}
\hline & 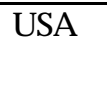 & $\begin{array}{l}\text { New } \\
\text { York }\end{array}$ & $\begin{array}{c}\text { Los } \\
\text { Angeles }\end{array}$ & Chicago & Houston & Atlanta & $\overline{~ C A N A D A ~}$ & Toronto & Vancouver & Montreal & Calgary & Ottawa \\
\hline USA & 1.00 & & & & & & & & & & & \\
\hline New York & 0.73 & 1.00 & & & & & & & & & & \\
\hline Los Angeles & 0.77 & 0.48 & 1.00 & & & & & & & & & \\
\hline Chicago & 0.81 & 0.59 & 0.69 & 1.00 & & & & & & & & \\
\hline Houston & 0.14 & -0.36 & 0.14 & -0.18 & 1.00 & & & & & & & \\
\hline Atlanta & 0.66 & 0.68 & 0.26 & 0.42 & 0.13 & 1.00 & & & & & & \\
\hline CANADA & 0.62 & 0.52 & 0.64 & 0.83 & -0.26 & 0.32 & 1.00 & & & & & \\
\hline Toronto & 0.52 & 0.63 & 0.55 & 0.62 & -0.38 & 0.45 & 0.81 & 1.00 & & & & \\
\hline Vancouver & 0.09 & -0.06 & 0.35 & 0.44 & -0.21 & -0.19 & 0.62 & 0.38 & 1.00 & & & \\
\hline Montreal & 0.71 & 0.70 & 0.69 & 0.82 & -0.27 & 0.42 & 0.82 & 0.69 & 0.40 & 1.00 & & \\
\hline Calgary & 0.42 & -0.09 & 0.52 & 0.47 & 0.38 & 0.15 & 0.47 & 0.34 & 0.50 & 0.30 & 1.00 & \\
\hline Ottawa & 0.45 & 0.53 & 0.37 & 0.48 & -0.02 & 0.31 & 0.25 & 0.17 & -0.04 & 0.57 & -0.23 & 1.00 \\
\hline
\end{tabular}

Table 5b: Concordance Between Metro Level and National Level House Price Cycles:

Share of Sample Cities in the Same Phase as National Level Cycle

\begin{tabular}{lcccccccc}
\hline \hline & \multicolumn{2}{c}{ US /US } & \multicolumn{2}{c}{ CAN /CAN } & US National /CAN Cities & CAN National /U.S. Cities \\
& Expansion & Contraction & Expansion & Contraction & Expansion & Contraction & Expansion & Contraction \\
Mean & $76.2 \%$ & $70.5 \%$ & $76.0 \%$ & $69.8 \%$ & $77.0 \%$ & $71.9 \%$ & $68.3 \%$ & $54.8 \%$ \\
Std. Dev. & $19.4 \%$ & $15.3 \%$ & $23.7 \%$ & $22.7 \%$ & $20.9 \%$ & $24.0 \%$ & $25.7 \%$ & $27.1 \%$ \\
\hline
\end{tabular}


Table 6: Summary Statistics for Covariates

\begin{tabular}{lccccc}
\hline \hline Variable Description & & Mean & Median & Stdev & $\mathrm{N}$ \\
Growth in Real House Prices (\%) & GHPI & 1.5 & 1.1 & 5.7 & 3191 \\
Growth in Real Income (\%) & GINC & 2.7 & 2.6 & 2.7 & 3191 \\
Growth in Population (\%) & GPOP & 1.3 & 1.2 & 1.25 & 3191 \\
Real Income per Capita (1997 dollars) & INCCAP & 23191.47 & 23927.79 & 8482.55 & 3191 \\
Growth in Income per Capita & GINCCAP & 1.3 & 1.4 & 2.4 & 3191 \\
Nominal Policy Rate (\%) & NPOLICY & 6.5 & 5.9 & 3.5 & 3191 \\
Real Policy Rate (\%) & RPOLICY & 3 & 3.4 & 2 & 3191 \\
Real Mortgage Rate (\%) & RM & 5.6 & 5.3 & 2.2 & 3190 \\
$\begin{array}{l}\text { Mortgage Loan-to-Value Ratio (\%) (US } \\
\text { only) }\end{array}$ & LTV & 76.3 & 76.7 & 3.9 & 2806 \\
\hline
\end{tabular}

Table 7: Results of Stationarity Tests for Key Variables

\begin{tabular}{|c|c|c|c|}
\hline \multirow[t]{2}{*}{ Variable Description } & & \multicolumn{2}{|c|}{$\begin{array}{l}p \text {-values from Im-Pesaran-Shin } W \text {-Test for Pane } \\
\text { Variables, or Phillips Perron Test for Aggregat } \\
\text { Macro Variables . H0: Variable is I }(1)^{*}\end{array}$} \\
\hline & & US Data & Canadian Data \\
\hline Real House Prices & RHPI & 1.00 & 0.00 \\
\hline Growth of Real House Prices & GRHPI & 0.00 & 0.00 \\
\hline Real Income /Capita [2 lags] & INCCAP & 1.00 & 0.78 \\
\hline Growth of Income /Capita & GINCCAP & 0.00 & 0.00 \\
\hline Growth of Real Income & GINC & 0.00 & 0.00 \\
\hline Growth of Population & GPOP & 0.00 & 0.00 \\
\hline Duration in the Current Phase & DUR & 0.00 & 0.00 \\
\hline Amplitude of the Current Phase & AMPPCT & 0.27 & 0.03 \\
\hline Mortgage Loan-to-Value Ratio & LTV & 0.21 & n.a. \\
\hline Detrended LTV Ratio & DTLTV & 0.00 & n.a. \\
\hline Real Mortgage Rate & $R M$ & 0.14 & 0.27 \\
\hline Change in Real Mortgage Rate & $D R M$ & 0.00 & 0.00 \\
\hline Nominal Policy Rate & NPOLICY & 0.52 & 0.61 \\
\hline Change in Nominal Policy Rate & DNPOLICY & 0.00 & 0.00 \\
\hline Real Policy Rate & RPOLICY & 0.13 & 0.04 \\
\hline Change in Real Policy Rate & DRPOLICY & 0.00 & 0.00 \\
\hline
\end{tabular}


Table 8: Duration Dependence Regression Results for Expansions

(absolute values of robust $t$-statistics in parentheses)

\begin{tabular}{|c|c|c|c|c|c|c|c|c|c|}
\hline & 1 & 2 & 3 & 4 & 5 & 6 & 7 & 8 & 9 \\
\hline $\operatorname{DUR}(t-1)$ & $\begin{array}{c}0.010^{* * *} \\
(4.13)\end{array}$ & & $\begin{array}{c}0.008^{* * *} \\
(3.54)\end{array}$ & & & & & & \\
\hline DUR3 & & $\begin{array}{c}0.048^{* * *} \\
(2.66)\end{array}$ & & $\begin{array}{c}0.043^{* * *} \\
(2.47)\end{array}$ & $\begin{array}{l}0.043^{* *} \\
(2.46)\end{array}$ & $\begin{array}{c}0.049^{* * *} \\
(3.03)\end{array}$ & $\begin{array}{c}0.049^{* * *} \\
(3.40)\end{array}$ & $\begin{array}{l}0.046^{* *} \\
(2.45)\end{array}$ & $\begin{array}{l}0.043^{* *} \\
(2.47)\end{array}$ \\
\hline DUR4 & & $\begin{array}{c}0.063^{* * *} \\
(3.31)\end{array}$ & & $\begin{array}{c}0.054^{* *} \\
(2.82)\end{array}$ & $\begin{array}{l}0.055^{*} \\
(2.84)\end{array}$ & $\begin{array}{c}0.046^{* *} \\
(2.42)\end{array}$ & $\begin{array}{c}0.046^{* *} \\
(1.97)\end{array}$ & $\begin{array}{l}0.051^{* *} \\
(2.49)\end{array}$ & $\begin{array}{c}0.055^{*} \\
(2.86)\end{array}$ \\
\hline DUR5 & & $\begin{array}{l}0.017 \\
(0.81)\end{array}$ & & $\begin{array}{l}0.031 \\
(1.45)\end{array}$ & $\begin{array}{c}0.03 \\
(1.41)\end{array}$ & $\begin{array}{l}0.016 \\
(0.78)\end{array}$ & $\begin{array}{l}0.016 \\
(0.69)\end{array}$ & $\begin{array}{l}0.037 \\
(1.64)\end{array}$ & $\begin{array}{c}0.03 \\
(1.41)\end{array}$ \\
\hline DUR6 & & $\begin{array}{l}0.009 \\
(0.37)\end{array}$ & & $\begin{array}{l}0.016 \\
(0.72)\end{array}$ & $\begin{array}{l}0.015 \\
(0.66)\end{array}$ & $\begin{array}{l}0.008 \\
(0.36)\end{array}$ & $\begin{array}{l}0.008 \\
(0.23)\end{array}$ & $\begin{array}{l}0.014 \\
(0.59)\end{array}$ & $\begin{array}{l}0.015 \\
(0.67)\end{array}$ \\
\hline DUR7 & & $\begin{array}{l}0.024 \\
(0.91)\end{array}$ & & $\begin{array}{l}0.011 \\
(0.40)\end{array}$ & $\begin{array}{l}0.009 \\
(0.33)\end{array}$ & $\begin{array}{l}-0.01 \\
(0.34)\end{array}$ & $\begin{array}{l}-0.01 \\
(0.24)\end{array}$ & $\begin{array}{l}0.009 \\
(0.29)\end{array}$ & $\begin{array}{l}0.009 \\
(0.33)\end{array}$ \\
\hline DUR8 & & $\begin{array}{l}0.053^{*} \\
(1.70)\end{array}$ & & $\begin{array}{l}0.039 \\
(1.17)\end{array}$ & $\begin{array}{l}0.037 \\
(1.10)\end{array}$ & $\begin{array}{l}0.023 \\
(0.69)\end{array}$ & $\begin{array}{l}0.023 \\
(0.64)\end{array}$ & $\begin{array}{l}0.044 \\
(1.22)\end{array}$ & $\begin{array}{l}0.037 \\
(1.09)\end{array}$ \\
\hline DUR10UP & & $\begin{array}{c}0.116^{\text {*** }} \\
(3.60)\end{array}$ & & $\begin{array}{c}0.107^{* * *} \\
(3.38)\end{array}$ & $\begin{array}{c}0.107^{* * *} \\
(3.33)\end{array}$ & $\begin{array}{c}0.097^{* * *} \\
(3.09)\end{array}$ & $\begin{array}{c}0.097^{* * *} \\
(5.20)\end{array}$ & $\begin{array}{c}0.111^{\text {*** }} \\
(3.36)\end{array}$ & $\begin{array}{c}0.107^{* * *} \\
(3.35)\end{array}$ \\
\hline GINC & & & $\begin{array}{c}0.028^{* * *} \\
(8.96)\end{array}$ & $\begin{array}{c}0.028^{* * *} \\
(8.91)\end{array}$ & & & & & \\
\hline GPOP & & & $\begin{array}{c}-0.023^{* *} \\
(3.89)\end{array}$ & $\begin{array}{c}-0.023^{* *} \\
(4.10)\end{array}$ & & & & & \\
\hline DRM & & & $\begin{array}{c}-0.013^{*} \\
(1.89)\end{array}$ & $\begin{array}{c}-0.014^{* *} \\
(2.23)\end{array}$ & $\begin{array}{c}-0.014^{* *} \\
(2.18)\end{array}$ & & & $\begin{array}{c}-0.016^{* *} \\
(2.40)\end{array}$ & $\begin{array}{l}-0.014 \\
(2.18)\end{array}$ \\
\hline GINCCAP & & & & & $\begin{array}{c}0.028^{* * *} \\
(8.91)\end{array}$ & $\begin{array}{c}0.031^{* * *} \\
(9.76)\end{array}$ & $\begin{array}{l}0.031^{* * *} \\
(16.67)\end{array}$ & $\begin{array}{c}0.027^{* * *} \\
(8.23)\end{array}$ & $\begin{array}{c}0.028^{4} \\
(8.95)\end{array}$ \\
\hline DRPOLICY & & & & & & $\begin{array}{c}-0.03^{* * *} \\
(7.02)\end{array}$ & & & \\
\hline DNPOLICY & & & & & & & $\begin{array}{c}-0.03^{* * *} \\
(4.20)\end{array}$ & & \\
\hline DTLTV & & & & & & & & $\begin{array}{l}0.000 \\
(0.08)\end{array}$ & \\
\hline CANADA & & & & & & & & & $\begin{array}{l}0.016 \\
(0.76)\end{array}$ \\
\hline Obs & 2223 & 2245 & 2106 & 2137 & 2137 & 2138 & 2138 & 1913 & 2137 \\
\hline SDUR $(p)$ & & 0.00 & & 0.00 & 0.00 & 0.00 & 0.00 & 0.00 & 0.00 \\
\hline LL & -774.79 & -795.1 & -709.83 & -727.72 & -728.36 & -700.61 & -700.61 & -662.21 & -728.08 \\
\hline Pseudo R 2 & 0.01 & 0.02 & 0.07 & 0.09 & 0.09 & 0.13 & 0.13 & 0.09 & 0.09 \\
\hline
\end{tabular}

Note: All models are estimated with probit MLE and include a constant term and robust standard errors to control for heteroskedasticity. The model is estimated with dprobit in Stata. The reported coefficients are the estimated change in the probability that the dependent variable equals 1 given an infinitesimal change in the regressor variable (or a discrete change in the for dummy variable regressors). Specifications with GINC or GINCCAP include data to 2004 only. Model 8 only uses observations for U.S. cities since LTV ratios were not available for Canada. SDUR $(p)$ is the p-value for a joint hypothesis test that the duration dummies sum to zero. 
Table 9: Duration Dependence Regression Results for Contractions (absolute values of robust $t$-statistics in parentheses)

\begin{tabular}{|c|c|c|c|c|c|c|c|c|c|}
\hline & 1 & 2 & 3 & 4 & 5 & 6 & 7 & 8 & 9 \\
\hline $\operatorname{DUR}(t-1)$ & $\begin{array}{c}-0.016^{* * *} \\
(3.18)\end{array}$ & & $\begin{array}{c}-0.012^{* * *} \\
(2.39)\end{array}$ & & & & & & \\
\hline DUR3 & & $\begin{array}{l}0.024 \\
(0.79)\end{array}$ & & $\begin{array}{l}0.037 \\
(1.37)\end{array}$ & $\begin{array}{l}0.039 \\
(1.45)\end{array}$ & $\begin{array}{c}0.071^{* * *} \\
(2.87)\end{array}$ & $\begin{array}{c}0.071^{* * *} \\
(4.89)\end{array}$ & $\begin{array}{l}0.027 \\
(0.97)\end{array}$ & $\begin{array}{l}0.037 \\
(1.38)\end{array}$ \\
\hline DUR4 & & $\begin{array}{l}0.027 \\
(0.80)\end{array}$ & & $\begin{array}{c}0.073^{* * *} \\
(2.45)\end{array}$ & $\begin{array}{c}0.071^{* *} \\
(2.30)\end{array}$ & $\begin{array}{l}0.06^{* * *} \\
(2.06)\end{array}$ & $\begin{array}{c}0.06 \\
(1.19)\end{array}$ & $\begin{array}{c}0.065^{* *} \\
(2.14)\end{array}$ & $\begin{array}{c}0.068^{* *} \\
(2.22)\end{array}$ \\
\hline DUR5 & & $\begin{array}{r}-0.001 \\
(0.02)\end{array}$ & & $\begin{array}{c}0.04 \\
(1.21)\end{array}$ & $\begin{array}{c}0.04 \\
(1.19)\end{array}$ & $\begin{array}{l}0.023 \\
(0.73)\end{array}$ & $\begin{array}{l}0.023 \\
(0.81)\end{array}$ & $\begin{array}{l}0.028 \\
(0.83)\end{array}$ & $\begin{array}{l}0.036 \\
(1.08)\end{array}$ \\
\hline DUR6 & & $\begin{array}{r}-0.008 \\
(0.19)\end{array}$ & & $\begin{array}{l}0.027 \\
(0.73)\end{array}$ & $\begin{array}{l}0.027 \\
(0.73)\end{array}$ & $\begin{array}{r}-0.012 \\
(0.34)\end{array}$ & $\begin{array}{r}-0.012 \\
(0.19)\end{array}$ & $\begin{array}{l}0.008 \\
(0.21)\end{array}$ & $\begin{array}{l}0.022 \\
(0.58)\end{array}$ \\
\hline DUR7 & & $\begin{array}{r}-0.014 \\
(0.29)\end{array}$ & & $\begin{array}{l}0.030 \\
(0.73)\end{array}$ & $\begin{array}{l}0.035 \\
(0.84)\end{array}$ & $\begin{array}{l}0.004 \\
(0.09)\end{array}$ & $\begin{array}{l}0.004 \\
(0.06)\end{array}$ & $\begin{array}{l}0.034 \\
(0.81)\end{array}$ & $\begin{array}{l}0.033 \\
(0.79)\end{array}$ \\
\hline DUR8 & & $\begin{array}{c}-0.133^{* * *} \\
(2.07)\end{array}$ & & $\begin{array}{r}-0.031 \\
(0.60)\end{array}$ & $\begin{array}{r}-0.024 \\
(0.47)\end{array}$ & $\begin{array}{r}-0.054 \\
(1.07)\end{array}$ & $\begin{array}{r}-0.054 \\
(0.80)\end{array}$ & $\begin{array}{c}-0.047 \\
(0.87)\end{array}$ & $\begin{array}{r}-0.028 \\
(0.54)\end{array}$ \\
\hline DUR9 & & $\begin{array}{c}-0.576^{* * *} \\
(5.27)\end{array}$ & & $\begin{array}{c}-0.448^{* * *} \\
(4.06)\end{array}$ & $\begin{array}{c}-0.445^{* * *} \\
(4.07)\end{array}$ & $\begin{array}{c}-0.468^{* * *} \\
(4.41)\end{array}$ & $\begin{array}{c}-0.468^{* * *} \\
(3.24)\end{array}$ & $\begin{array}{c}-0.51^{* * *} \\
(4.35)\end{array}$ & $\begin{array}{c}-0.447^{* * *} \\
(4.00)\end{array}$ \\
\hline DUR10UP & & $\begin{array}{c}-0.316^{* *} \\
(2.00)\end{array}$ & & $\begin{array}{r}-0.213 \\
(1.58)\end{array}$ & $\begin{array}{r}-0.213 \\
(1.52)\end{array}$ & $\begin{array}{r}-0.205 \\
(1.53)\end{array}$ & $\begin{array}{c}-0.205^{* * *} \\
(2.83)\end{array}$ & $\begin{array}{c}-0.233^{*} \\
(1.68)\end{array}$ & $\begin{array}{c}-0.224 \\
(1.60)\end{array}$ \\
\hline GINC & & & $\begin{array}{c}-0.047^{* * *} \\
(10.16)\end{array}$ & $\begin{array}{c}-0.046^{* * *} \\
(10.41)\end{array}$ & & & & & \\
\hline GPOP & & & $\begin{array}{c}0.018^{* * *} \\
(2.03)\end{array}$ & $\begin{array}{c}0.022^{* *} \\
(2.60)\end{array}$ & & & & & \\
\hline$D R M$ & & & $\begin{array}{c}0.018^{* * *} \\
(3.16)\end{array}$ & $\begin{array}{c}0.019^{* * *} \\
(3.56)\end{array}$ & $\begin{array}{c}0.018^{* * *} \\
(3.44)\end{array}$ & & & $\begin{array}{c}0.015^{* *} \\
(2.77)\end{array}$ & $\begin{array}{c}0.017^{* * *} \\
(3.20)\end{array}$ \\
\hline GINCCAP & & & & & $\begin{array}{c}-0.047^{* * *} \\
(10.42)\end{array}$ & $\begin{array}{c}-0.052^{* * *} \\
(11.90)\end{array}$ & $\begin{array}{c}-0.052^{* * *} \\
(13.37)\end{array}$ & $\begin{array}{c}-0.048^{* * *} \\
(10.41)\end{array}$ & $\begin{array}{c}-0.048^{* * *} \\
(10.69)\end{array}$ \\
\hline DRPOLICY & & & & & & $\begin{array}{c}0.047^{* * *} \\
(9.34)\end{array}$ & & & \\
\hline DNPOLICY & & & & & & & $\begin{array}{l}0.047^{* * *} \\
(11.35)\end{array}$ & & \\
\hline DTLTV & & & & & & & & $\begin{array}{l}0.000 \\
(0.13)\end{array}$ & \\
\hline CANADA & & & & & & & & & $\begin{array}{c}-0.092^{* *} \\
(2.25)\end{array}$ \\
\hline Obs & 1507 & 1572 & 1507 & 1572 & 1572 & 1572 & 1572 & 1445 & 1572 \\
\hline $\operatorname{SDUR}(p)$ & & 0.00 & & 0.15 & 0.17 & 0.06 & 0.10 & 0.05 & 0.13 \\
\hline LL & -739.47 & -752.27 & -663.15 & -676.9 & -682.34 & -640.14 & -640.14 & -607.72 & -679.69 \\
\hline Pseudo R2 & 0.01 & 0.03 & 0.11 & 0.12 & 0.12 & 0.17 & 0.17 & 0.14 & 0.12 \\
\hline
\end{tabular}


Table 10: Benchmark Regressions: Tests of Duration Dependence with Decade Controls (absolute values of robust $t$-statistics in parentheses)

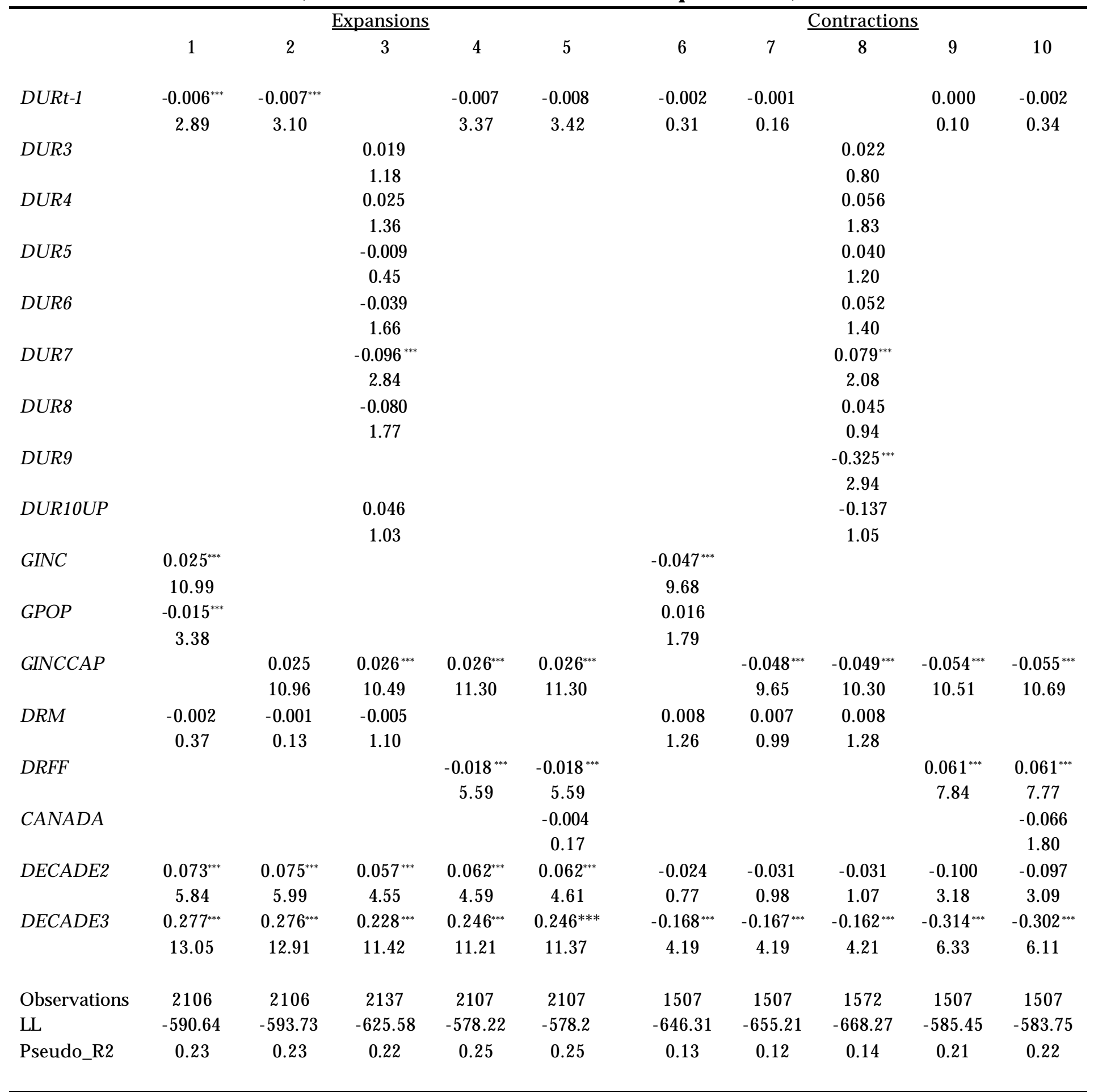

See note to Table 8. DECADEvariables are dummy variables where the reference group is the years from 1975 to 1984 . DECADE2 equals 1 in the years 1985 to 1994 , and DECADE3 equals 1 in 1995 and later years. 
Table 11: Robustness Tests of Duration Dependence Regressions (absolute values of robust $t$-statistics in parentheses)

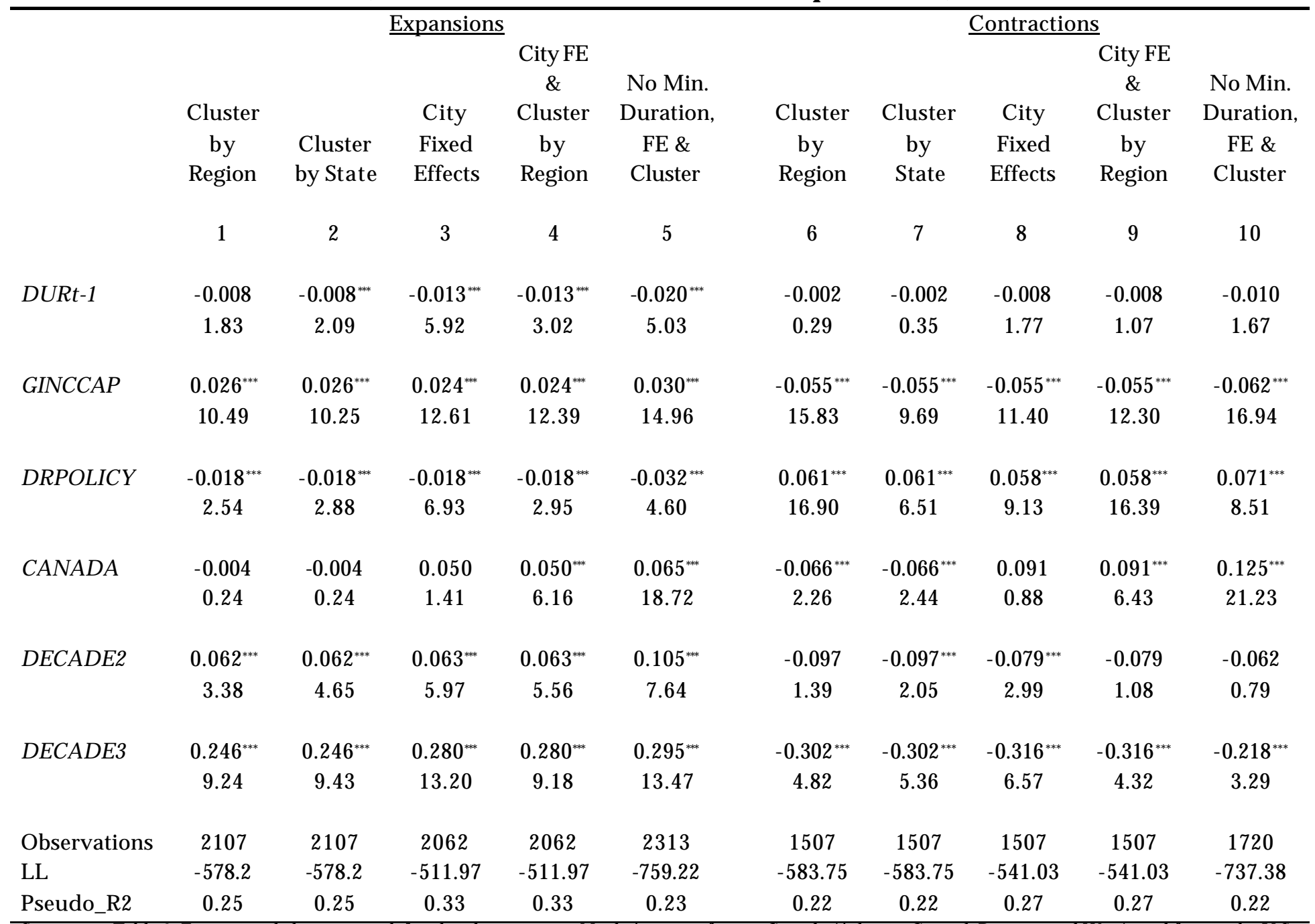

See note to Table 8. For regional clusters, we defined eight regions in North America, four in Canada (Atlantic, Central, Prairies, and West), and four in the U.S. (South, Northeast, Midwest and West). For state level clustering, any metro areas that belonged to several states were assigned to the first state listed. 


\section{Appendix A: Data Sources and Variable Construction}

\begin{tabular}{ll}
\hline \multicolumn{1}{c}{ Variable } & \\
$\begin{array}{l}\text { US Nominal House Price Index } \\
\text { Canadian Nominal Average Selling Home } \\
\text { Price }\end{array}$ & Office of Federal Housing Oversight \\
Consumer Price Index & Multiple Listing Service \\
$\begin{array}{l}\text { US Nominal 30 Year Conventional Mortgage } \\
\text { Rate } \\
\text { Canadian Nominal } 5 \text { Year Conventional } \\
\text { Mortgage Rate }\end{array}$ & Bureau of Labor Statistics and Statistics Canada \\
Nominal Policy Interest Rate & St. Louis Federal Reserve \\
Nominal Personal Income & Sank Canada \\
Population & Bureau of Economic Analysis and Statistics Canada \\
U.S. Mortgage Loan-to-Value Ratio & Bureau of Economic Analysis and Statistics Canada \\
\hline
\end{tabular}

We construct U.S. real house price indices using the metro and national level mominal house price indices (HPI) from the Office of Federal Housing Enterprise Oversight (OFHEO), deflated by the all urban CPI data published by the Bureau of Labor Statistics.

OFHEO's House Price Index is published on a quarterly basis and tracks average house price changes in repeat sales or refinancings of the same single-family properties. OFHEO produces the house price index for 379 metro areas as well as for the State and National level. OFHEO's index is based on analysis of mortgage records data on more than 30.1 million repeat transactions over the past 30 years, obtained from the government sponsored enterprises, Fannie Mae and Freddie Mac. These mortgage records are limited to conventional, conforming mortgage transactions, and thus do not include nonconforming or nontraditional mortgage arrangements. The current conforming loan limit is $\$ 417,000$. Changes in the mix of data from refinancings and house purchase transactions can affect HPI results. For example, because the OFHEO data set only contains mortgage lending below $\$ 417,000$ many homes are omitted from the data set. Several metropolitan areas (most notably California) require home owners to borrow well in excess of this amount to finance home ownership. Furthermore, the index omits 
new home sales, which account for nearly $20 \%$ of U.S. home sales, as well as condominiums, and multiple-family dwellings. Finally, the OFHEO data may overstate the pure appreciation in house prices somewhat because it does not take into account remodeling and quality increases. Despite these limitations the OFHEO dataset has several distinct advantages. The OFHEO price index eliminates the upward bias that other price measures contain as it attempts to measure the constant quality of a home.

Other house price indicators such as the median existing selling price produced by the National Association of Realtors (NAR) contain an upward bias as they do not control for quality improvements. Another drawback from the NAR series is that it is not a fixed weight series so that, for example, a surge in sales of high-priced single-family units would drive the index higher. By not using fixed weights for the various housing types, the reported price measure is vulnerable to so called quantity shifts. In other words, there is the risk that a change in the index level may not be solely attributable to a change in the price of housing.

Other U.S. data includes nominal metro level personal income and population, the nominal federal funds and conventional mortgage rates, and the average mortgage loan-to-value ratio (LTV). ${ }^{16}$ All nominal variables (for both the U.S. and Canada) are deflated using the national level consumer price index series. Nominal interest rates are deflated by subtracting the annual inflation rate from the nominal interest rate.

Canadian house prices can be measured using the average selling price compiled using data from the multiple listing service (MLS). The MLS series is then deflated using the Canadian national consumer price index from Statistics Canada. The geographic areas included in the MLS data are: Canada, St. John's, Montreal, Ottawa, Toronto, Hamilton, London, Winnipeg, Regina, Calgary, Edmonton and Vancouver. The Canadian explanatory variables differ somewhat from the U.S. regressors. As metro-level population, personal income and mortgage LTV ratios are not

\footnotetext{
16 The average mortgage LTV ratio is based on fully amortized mortgage loans used to purchase single -family nonfarm homes and only includes data on new mortgage originations. Loans used to refinance houses are excluded, as are non-amortized and exotic mortgage products. Mortgage loan-to-value ratios are unavailable for the Canadian market at this time.
} 
available for Canada, we are forced to either use provincial level aggregates (for personal income and population), or omit the series from our regression analysis. 


\section{Appendix B: Discrete Time Survival Model}

The following section follows the exposition in Jenkins (1995). Suppose we are attempting to explain the duration of house price expansion cycles. We index the metro areas by $i=1, \ldots n$ and the passage of time (in our case years) as $t=1,2, \ldots$. Let $t=\tau$ represent the sample selection year. In effect tau represents the beginning of the newly observed spell. Then we can let $t=\tau+s_{i}$ index the point a particular metro is in within a spell.

Duration models are modeled using the probabilities of ending a spell at each time period $t$. One minus this probability is commonly referred to as the "survival probability". As Jenkins notes "there is a one-to-one relationship between these probabilities - 'hazard rates'- and the probabilities of having completed spell durations of different lengths - summarized by the 'survivor function'. The hazard rate in a discrete time framework is

$$
h_{i t}=\operatorname{Pr}\left(T_{i}=t \mid T_{i} \geq t ; X_{i t}\right)
$$

This hazard function says that the probability of metro $i$ changing states in the current time period is conditional on the fact that the metro has not changed states in previous periods and has a specific set of covariates.

Jenkins (1995) shows that the conditional probability of observing a metro area that continues in its current state is:

$$
\operatorname{Pr}\left(T_{i}>t+s \mid T_{i}>\tau-1\right)=\prod_{t=\tau}^{\tau+s_{i}}\left(1-h_{i t}\right)
$$

Equation $X$ states that the probability of survival in the current period is conditional on the product of all the survivor probabilities up to the current time period in the spell. Alternatively the conditional probability of observing a metro area completing a spell and exiting during the observed interval of time is: 


$$
\operatorname{Pr}\left(T_{i}=t+s_{i} \mid T_{i}>\tau-1\right)=\left[h_{i \tau+s_{i}} /\left(1-h_{i \tau+s_{i}}\right)\right] \prod_{t=\tau}^{\tau+s_{i}}\left(1-h_{i t}\right)
$$

The likelihood function is then the likelihood of observing the event over the entire data set and is made up of contributions from metro areas that exit a state in a given time interval and those that survive.

$$
\ell=\prod_{i=1}^{n}\left[\left[h_{i \tau+s_{i}} /\left(1-h_{i \tau+s_{i}}\right)\right] \prod_{t=\tau}^{+s_{i}}\left(1-h_{i t}\right)\right]^{\left(1-\delta_{i}\right)}\left[\prod_{t=\tau}^{\tau+s_{i}}\left(1-h_{i t}\right)\right]^{\delta_{i}}
$$

where $d_{i}=1$ if metro $i$ continues in the same state in period $t$, and $d_{i}=0$ if metro $i$ exits the current state in period $t$. If we take the log of this function we get the log-likelihood function.

$$
\log \ell=\sum_{i=1}^{n}\left(1-\delta_{i}\right) \log \llbracket h_{i \tau+s_{i}} /\left(1-h_{i \tau+s_{i}}\right) \rrbracket+\sum_{i=1}^{n} \sum_{t=\tau}^{t+s_{i}} \log \left(1-h_{i t}\right)
$$

To estimate (5) we define the dependant binary variable $y_{i t}=1$ for all years the city remains in the phase and zero when the metro area exits the spell.

$$
\left.\left.\log \ell=\sum_{i=1}^{n} \sum_{t=\tau}^{\tau+s_{i}}\left(1-y_{i t}\right) \log \llbracket h_{i t} /\left(1-h_{i t}\right)\right]\right]+\sum_{i=1}^{n} \sum_{t=\tau}^{\tau+s_{j}} \log \left(1-h_{i t}\right)
$$

Next we express the survivor function $\left(1-h_{i t}\right)$, as a probit specification with duration in the current phase as one of the regressors.

$$
\operatorname{Pr}(\text { Current State Continuing })=\operatorname{Pr}\left(y_{i t}=1\right)=\operatorname{Pr}\left(1-h_{i t}\right)=\Phi(X \beta)
$$

Where $X$ refers to duration and the other covariates (growth of real income per capita, real mortgage rates, etc.) and $\mathrm{F}$ is the cumulative normal distribution. 